NBER WORKING PAPER SERIES

\title{
THE FISCAL COST OF HURRICANES: DISASTER AID VERSUS SOCIAL INSURANCE
}

\author{
Tatyana Deryugina \\ Working Paper 22272 \\ http://www.nber.org/papers/w22272 \\ NATIONAL BUREAU OF ECONOMIC RESEARCH \\ 1050 Massachusetts Avenue \\ Cambridge, MA 02138 \\ May 2016
}

I thank Matthew Shapiro and two anonymous referees for helpful comments that significantly improved the paper. I am very grateful to Amy Finkelstein and Michael Greenstone for invaluable feedback and guidance. I thank Kathy Baylis, Jeff Brown, Joseph Doyle, Kerry Emanuel, Don Fullerton, Josh Gottlieb, Tal Gross, Jerry Hausman, Daniel Keniston, Patrick Kline, Steven Levitt, Randall Lewis, Anup Malani, Gilbert Metcalf, Erwann Michel-Kerjan, Nolan Miller, Kevin Murphy, Mariya Pivtoraiko, Jim Poterba, Mar Reguant, Julian Reif, Joseph Shapiro, and Chad Syverson for useful discussions and feedback. I also thank participants at the NBER Universities' Research Conference, the MIT Public Finance Lunch and Political Economy Breakfast, the University of Chicago Applied Microeconomics Lunch, and the Harvard Environmental Economics Lunch. A big thanks goes to Stephanie Sieber for help with spatial data. Jenna Weinstein provided excellent research assistance. Support from the MIT Energy Fellowship and the National Science Foundation is gratefully acknowledged. The views expressed herein are those of the author and do not necessarily reflect the views of the National Bureau of Economic Research.

NBER working papers are circulated for discussion and comment purposes. They have not been peer-reviewed or been subject to the review by the NBER Board of Directors that accompanies official NBER publications.

(C) 2016 by Tatyana Deryugina. All rights reserved. Short sections of text, not to exceed two paragraphs, may be quoted without explicit permission provided that full credit, including () notice, is given to the source. 
The Fiscal Cost of Hurricanes: Disaster Aid Versus Social Insurance

Tatyana Deryugina

NBER Working Paper No. 22272

May 2016

JEL No. H53,H84,Q54

\begin{abstract}
$\underline{\text { ABSTRACT }}$
Little is known about the fiscal costs of natural disasters, especially regarding social safety nets that do not specifically target extreme weather events. This paper shows that US hurricanes lead to substantial increases in non-disaster government transfers, such as unemployment insurance and public medical payments, in affected counties in the decade after a hurricane. The present value of this increase significantly exceeds that of direct disaster aid. This implies, among other things, that the fiscal costs of natural disasters have been significantly underestimated and that victims in developed countries are better insured against them than previously thought.
\end{abstract}

Tatyana Deryugina

Department of Finance

University of Illinois at Urbana-Champaign

515 East Gregory Drive, MC-520

Champaign, IL 61820

and NBER

deryugin@illinois.edu

A data appendix is available at http://www.nber.org/data-appendix/w22272 
Economic shocks due to extreme weather are significant and expected to grow in magnitude due to population movements, ecosystem alteration, and climate change (Board on Natural Disasters, 1999; IPCC, 2012, 2013). Consequently, real disaster costs are high and growing faster than GDP (Freeman, Keen and Mani, 2003; Bouwer et al., 2007). While much research has been done on the direct damage inflicted by extreme weather and on the impact of natural disasters on incomes and employment, relatively little attention has been paid to the fiscal cost of the aid response, which is often substantial. Less attention still has been paid to the costs borne by social safety net programs, such as traditional unemployment insurance, that do not target disaster victims specifically, but which may be triggered by such events. Transfers from traditional social safety nets provide insurance against natural disasters and could be delivering substantial benefits to victims. At the same time, because the costs of such transfers are not covered by the recipients, moral hazard problems may lead individuals to live in riskier places and take fewer precautions than they would with actuarially fair insurance. More generally, measuring the fiscal costs of disasters is important for understanding governments' long-term budgeting needs, for illuminating the mechanisms behind disasters' economic impacts, and for painting a more complete picture of disasters' social costs.

This paper provides the first estimates of the fiscal costs of US hurricanes, taking into account both direct costs (i.e., through the disaster aid channel) and indirect costs (i.e., through other social safety net programs). Using data that span the years 1969-2012, I estimate changes in government non-disaster transfers received by individuals in US counties in the ten years following a hurricane strike. I focus on hurricanes that occurred in 1979-2002, which allows me to observe outcomes for 10 years before and after each hurricane. I employ a differences-in-differences framework, comparing counties that experience hurricanes with those that do not, to estimate how hurricanes affect transfers that are part of the broader social safety net, such as income maintenance payments, unemployment insurance, and public medical benefits. To provide context for these results and to understand the mechanisms that drive them, I also consider changes in other outcomes, including population, demographics, earnings, and employment.

My results show that considering disaster aid alone substantially understates the fiscal costs of natural disasters. Funds provided through official disaster declarations, i.e., disaster aid, average \$155-\$160 per capita per hurricane during my study period. By contrast, I estimate that in the ten years following a hurricane an affected county receives extra transfers through non-disaster social insurance programs averaging about $\$ 780-\$ 1,150$ per capita in present value. ${ }^{1}$ Another measure of transfers available to me includes private insurance payments as a component (referred to as "transfers from businesses to individuals" in my data). These transfers increase temporarily as well, but they add less than $\$ 25$ per capita to total transfers, with the majority of the increase

\footnotetext{
${ }^{1}$ All monetary amounts have been converted to 2013 dollars using the Consumer Price Index.
} 
occurring in the year of the hurricane.

Together, the disaster aid and social insurance transfers offset a substantial amount of hurricanes' immediate capital damage, which the Federal Emergency Management Agency (FEMA) estimates to be $\$ 700$ per capita for major (Category 3 and higher) hurricanes during my study period. I also find that counties are resilient following hurricane strikes: there is no systematic evidence of a drop in average earnings, and the employment rate is estimated to be significantly lower only 5-10 years afterwards. Similarly, population remains unchanged. Overall, the estimates show that (a) the fiscal impact of hurricanes in the US is much greater once we account for transfers through non-disaster social safety nets and (b) disaster aid and social insurance transfers together offset a large share of the damage of a typical US hurricane, implying that victims of such disasters in developed countries are better insured against them than previously thought. However, given the confidence intervals of the earnings estimates, I cannot rule out that victims experience a net loss of several hundred dollars per capita.

I contribute to two main strands in the literature. The first focuses on the response of local economies to shocks, typically focusing on outcomes such as employment, population, and wages (e.g., Blanchard and Katz, 1992; Card, 2001; Cortes, 2008; Autor, Dorn and Hanson, 2013). With the exception of Autor et. al. (2013), who study how labor markets in the US are affected by trade competition with China, the extant research ignores the fiscal costs of and response to these shocks. I show that the inflow of government funds into a county following a hurricane is substantial, exceeding official disaster aid on average. Thus, such shocks not only cause local economic damage but also incur a substantial fiscal cost. Moreover, while Autor et. al. (2013) find that transfers made through Trade Adjustment Assistance (or TAA, a program specifically aimed at helping workers hurt by trade) are two orders of magnitude smaller than transfers from general social safety net programs in per capita terms, I find that disaster-specific transfers to hurricane-affected counties are smaller but on the same order of magnitude as non-disaster transfers.

I also contribute to the literature on the economic impacts of natural disasters, which has typically focused on income. Studies in this area typically use GDP or GDP-equivalents as outcomes and thus miss disasters' impacts on government transfer payments. Consistent with my results, previous researchers have largely found very small or no long-run impacts on income in developed countries (e.g., Murphy and Strobl, 2010; Strobl, 2011). ${ }^{2}$ An important exception to this trend is a study by Hsiang and Jina (2014), who find that hurricanes reduce national incomes for at least twenty years in both developing and developed countries.

Few studies have examined employment or population in developed countries following natural disasters. Consistent with my estimates, Strobl (2011) finds that a US coastal county's overall

\footnotetext{
${ }^{2}$ For a more comprehensive review of the literature, see Cavallo and Noy (2010), Kousky (2012), and Bergeijk and Lazzaroni (2015).
} 
population is unchanged following a hurricane. Belasen and Polachek (2008) find that countylevel employment in Florida is lower for two years following a hurricane. I contribute to this literature by considering a much more comprehensive set of outcomes for a large set of disasters over a longer time period. Importantly, I show that ignoring non-disaster transfer flows, as the preceding literature does, paints an incomplete picture of post-disaster dynamics.

With the exception of Noy and Nualsri (2011), studies of financial flows in the aftermath of a disaster are either theoretical or focused on country-level measures of aid and remittances (Yang, 2008; Hochrainer, 2009; Cavallo and Noy, 2010). ${ }^{3}$ Noy and Nualsri (2011) examine countrylevel government spending and revenue dynamics following disasters, finding them to be countercyclical for developed countries. While I do not consider the cyclicality of transfers or the revenue that finances them, I am able to distinguish between disaster and non-disaster transfers and compare their magnitudes explicitly.

The rest of the paper is organized as follows. Section I provides background information on hurricanes, US federal disaster aid, and the data used for the analysis. Section II describes the empirical strategy. Sections III and IV present and discuss the results, respectively. Section V concludes.

\section{Background and Data}

\section{A Hurricane Damage in the United States}

Hurricanes that affect the US form in the Atlantic Ocean. Warm humid air over the ocean creates storms known as "tropical disturbances." If circulating winds develop, such a disturbance becomes a tropical cyclone. Prevailing winds and currents move the cyclone across the ocean, where it gains or loses strength, depending on conditions. Sometimes a circular area with low internal wind speeds, called the "eye," develops in the system's center. Although the entire storm system can span a few hundred miles, the strongest winds occur on the perimeter of the eye (the "eyewall"). Wind intensity diminishes quickly as one moves away from the eyewall (or the center of the storm, if it has no eye). The outer parts of the hurricane are called "spiral bands." These are characterized by heavy rains but typically do not carry hurricane-force winds. When a cyclone encounters land, it loses strength quickly. Thus, counties that are close to the coast bear the brunt of a storm's impact.

North Atlantic cyclones are classified by maximum 1-minute sustained wind speeds using the Saffir-Simpson Hurricane Scale. A "tropical storm" is a cyclone with wind speeds of 39-73 miles per hour. Cyclones with lower wind speeds are called "tropical depressions." A cyclone is considered a hurricane if maximum 1-minute sustained wind speeds exceed 74 miles per hour; I use

\footnotetext{
${ }^{3}$ For an in-depth conceptual discussion of relevant considerations when designing social safety nets to address natural disasters, see Pelham, Clay and Braunholz (2011).
} 
this cutoff value throughout. Category 1 and 2 hurricanes are "minor hurricanes," characterized by maximum wind speeds of 74-95 and 96-110 mph, respectively. Category 3-5 hurricanes have wind speeds greater than $111 \mathrm{mph}$ and are called "major hurricanes."

To track where hurricanes hit, I use the Hurricane Data 2nd generation (HURDAT2) dataset from the National Hurricane Center. ${ }^{4}$ It contains the storm center location, wind speed, and atmospheric pressure for each North Atlantic cyclone since 1851, in six-hour intervals. I assume that the storm path is linear between any two given points and that the wind speed changes smoothly. I supplement these data with the Extended Best Track Dataset, which has estimates of the "maximum wind speed radius" (MWSR), the distance between a cyclone's center, and the perimeter of the strongest winds for storms occurring in 1988 and later. ${ }^{5}$ The MWSR measures the spatial span of a hurricane's strongest winds. The MWSRs of earlier hurricanes are not available; I infer their MWSR based on their maximum wind speeds and pressure. ${ }^{6}$ I then assume that every county within the MWSR is affected. Although the hurricane data span a long time period, annual countylevel economic data are available for only 1969-2012. Because my econometric approach uses 10 leads and lags and a balanced panel of hurricanes, the storms in my analysis occurred between 1979 and 2002.

Between 1979 and 2002, two to eleven North Atlantic hurricanes formed each year, averaging six per year. Slightly more than one-third of these hurricanes reached major hurricane strength. Approximately one-third of all hurricanes made landfall, and about half of these were major hurricanes at some point in time. However, many hurricanes lose strength before making landfall. My sample period includes six years in which no storms made landfall at hurricane strength. Hurricanes that $d o$ make it to land cause widespread wind and flood damage: physical damage from hurricanes in the US has averaged $\$ 4.8$ billion per hurricane or $\$ 8.1$ billion per year between 1970 and 2005. If the year that Hurricane Katrina made landfall (2005) is excluded, that figure is \$2.4 billion per hurricane or $\$ 4.0$ billion per year. $^{7}$

US hurricanes are geographically concentrated, and only states close to the Atlantic and Gulf of Mexico coasts have ever experienced cyclones with hurricane-strength winds. Figure 1 shows the distribution of hurricane hits between 1979 and 2002, with darker areas indicating more hurricanes. In total, 409 counties experienced one or more hurricanes between 1979 and 2002 (282 experienced only one).

To gauge the potential economic impact of hurricanes, it is helpful to look more closely at the

\footnotetext{
${ }^{4}$ Available from http://www.aoml.noaa.gov/hrd/hurdat/Data_Storm.html. Accessed October 2013.

${ }^{5}$ Available from http://rammb.cira.colostate.edu/research/tropical_cyclones/tc_ extended_best_track_dataset/. Accessed February 2014.

${ }^{6}$ For more details, see Section 2 of the Online Appendix, which can be found at http://deryugina.com/ 2016-05-16-Deryugina-safety-net-Appendix.pdf.

${ }^{7}$ Author calculations using data from Nordhaus (2006).
} 
damage they cause. To assess hurricane damage, I use estimates of direct damage from HAZUS$\mathrm{MH}$, a software program published by FEMA to help state, local, and federal government officials prepare for disasters and to help the private sector estimate risk exposure. ${ }^{8}$ In addition to simulating hypothetical damage, HAZUS-MH contains highly detailed engineering-based damage estimates of past major hurricanes. ${ }^{9}$ In the Online Appendix, I also consider hurricane damage relative to other extreme weather events, showing that hurricanes are, on average, the most damaging of the common meteorological events in my sample (Table A2).

Table 1 shows county-level damage statistics for ten major hurricanes that made landfall in the United States from 1979 through 2002, including total loss, per capita loss, and the number of displaced households. Total loss includes estimates of structural damage to buildings, building content, and inventory loss. Panel A shows the estimated damage in counties that, by my calculations, were within the MWSR and experienced hurricane-strength winds (74 miles per hour or more). This sample corresponds to the way I identify hurricane-affected counties throughout the paper. The damage experienced by these counties is substantial: total loss averaged $\$ 200$ million or $\$ 700$ per capita, and about 520 households were displaced.

Panels B and C split up the sample in Panel A into counties that experienced wind speeds of 74-111 miles per hour (Panel B) and over 111 miles per hour (Panel C). Because wind's destructiveness rises non-linearly with speed, I expect the latter counties to suffer more damage. Indeed, counties in Panel B experience lower-than-average damage of $\$ 235$ per capita while counties with wind speeds of more than 111 miles per hour suffer damage of almost $\$ 4,100$ per capita.

Finally, Panel D shows the estimated effects of hurricanes on counties that are (a) considered to be affected in the FEMA simulations but are not within the MWSR and (b) direct neighbors of counties that are within an MWSR. The estimated damage is small: the average loss was only $\$ 1.9$ million, which is over 100 times smaller than the corresponding estimate in Panel A. Per capita total losses were about 20 times smaller, averaging only $\$ 32$ per capita. No households are estimated to have been displaced, on average. Including all affected neighboring counties in this summary whether or not they border counties within an MWSR makes the relative damage in MWSR counties even greater. Thus, using the MWSR to identify counties where hurricanes cause non-trivial damage is sensible.

\section{B Federal Disaster Aid}

A county can receive specially targeted federal disaster aid if the state's governor files a request and provides evidence that the state cannot manage the disaster on its own. The US president makes the final decision about whether to declare a disaster. If the request is approved, federal money can

\footnotetext{
${ }^{8}$ The software is available by request from http://www. fema.gov/hazus \#5.

${ }^{9}$ See Online Appendix Table A1 for the list of hurricanes, the estimated damage each caused, and the disaster aid each received.
} 
be used to repair public structures and to make individual and business grants and loans. FEMA also provides personnel, legal help, counseling, and special unemployment payments for those left unemployed by a disaster. Although long-term recovery spending is provided in some cases, most disaster-specific transfers to individuals occur within six months of a declaration, and most public infrastructure spending occurs within two to three years (FEMA, personal communication).

Between 1979 and 2002, the federal government spent \$19 billion on hurricane-related disaster aid and $\$ 67.7$ billion on other disasters through formal federal disaster declarations. ${ }^{10}$ The Northridge earthquake in 1994 (\$11.1 billion) and the World Trade Center attacks in 2001 (\$11.6 billion) caused a large fraction of the non-hurricane disaster spending. Excluding these two events implies that hurricane-related spending accounted for nearly half of all disaster aid during this period. Unfortunately, annual county-level data on spending specifically aimed at natural disasters is not available, so I cannot incorporate such spending into my main empirical framework. ${ }^{11}$ However, the available data allow me to approximate the amount of disaster-specific transfers per county.

Table 2 presents the summary statistics for federal aid related to hurricanes during 1979-2002. Because data on federal disaster aid is on the level of a declaration, which includes multiple counties in a state, I must assume how the money is divided among counties. As I show above, counties that fall within an MWSR experience much more damage than their neighbors. Therefore, one natural assumption is that the money is split among only those counties. Another natural assumption is that the money is divided among the included counties in proportion to the population in each county. A third natural assumption is that the money is divided in proportion to the wind speed. I applied all three of these assumptions in the analysis; the results are shown in separate columns in Table 2.

Panel A shows federal disaster aid transfers assuming that only counties that fall within an MWSR and experience hurricane-strength winds are given aid. If I assume that the money is split equally among all counties, the average per-hurricane amount of aid given to these counties was $\$ 15$ million per county or about $\$ 160$ per capita (Columns 1 and 4). Counties that were affected by the major hurricanes in the HAZUS-MH damage simulations and experienced hurricane-strength winds received slightly more on a per capita basis $(\$ 185)$. Of these, counties that experienced wind

\footnotetext{
${ }^{10}$ PERI Presidential Disaster Declarations database (Sylves and Racca, 2010). This number includes all declarationrelated spending by FEMA, including assistance given for infrastructure repair, individual grants, and mitigation spending. The Small Business Administration also offers subsidized loans to affected individuals and businesses, which are not included here. Spending by state and local governments is also excluded. By law, the state may be required to contribute to the relief effort, but its share of the total cannot exceed $25 \%$. Thus, accounting for state spending could increase these statistics by up to one-third.

${ }^{11}$ The Consolidated Federal Funds Report series, which begins in 1983, contains county-level information on disaster aid in principle. However, the bulk of disaster-related spending is assigned to state capital county areas rather than counties actually affected by the disaster, making it unusable for analysis.
} 
speeds of 74-111 miles per hour received $\$ 155$ per capita while those that experienced wind speeds of more than 111 miles per hour received $\$ 400$ per capita. The estimates are similar if I assume that the money is split in proportion to wind speed (Columns 3 and 5).

Panel B shows the same statistics assuming that the money is divided among all counties included in the declaration, not just those falling within an MWSR. Depending on which assumption about how the money is split applies, the implied per capita spending for MWSR counties ranges from $\$ 70$ to $\$ 100$. Hurricane-affected counties in the HAZUS-MH damage simulations received slightly more aid, between $\$ 105$ and $\$ 145$ per capita. Based on the previous analysis of damage to MWSR counties vis-a-vis their neighbors, it seems most reasonable to assume that the former receive all of the aid and that it is allocated between them in proportion to their populations or wind speeds (Columns 4 and 5 in Panel A). This assumption yields estimated disaster transfers of \$155$\$ 160$ per capita. In the following sections, I use this range as a benchmark to compare disaster relief spending with non-disaster transfer spending triggered by hurricanes. To compare disaster aid spending to damage estimates, which are only available for hurricanes in the HAZUS-MH simulations, I use the corresponding estimate of $\$ 180-\$ 185$ per capita.

It is worth noting that non-profit organizations, such as the Red Cross, may also play an important role in post-disaster dynamics. More broadly, charitable donations represent another potentially important transfer. For example, Americans donated an estimated $\$ 3.3$ billion to help victims of Hurricane Katrina, which struck the Gulf Coast in 2005, \$1.6 billion after the South Asian tsunami of 2004, and \$1.4 billion after the 2010 earthquake in Haiti (Charity Nagivator, n.d.). However, because there is no systematic data on charitable donations accruing to a particular area, I cannot capture the role of charities.

\section{Economic Data and Control Group}

Annual county-level data on population, wages, and government transfer payments come from the Regional Economic Information System (REIS), published by the Bureau of Economic Analysis. Annual county-level population by race and age are from the Surveillance Epidemiology and End Results (SEER) population database. Finally, data on employment is from the County Business Patterns (CBP) database. All three series span the years 1969-2012. ${ }^{12}$ I define the county employment rate as the ratio of total employment, as reported by $\mathrm{CBP}$, to the number of people aged fifteen and older, as reported by SEER. ${ }^{13}$ REIS reports wage and salary payments per capita, which I use to measure the average wage. REIS also contains a proxy for private insurance payments: transfers from businesses to individuals. This measure consists primarily of net insurance settlements and personal injury liability payments to non-employees. Thus, any changes in these transfers

\footnotetext{
${ }^{12}$ The underlying source of the population data in both REIS and SEER is the US Census Bureau. For details on how the annual population data are constructed, see the Online Appendix.

${ }^{13}$ Annual county-level unemployment rates are not available until 1990.
} 
following a hurricane are likely to be driven by insurance payouts. ${ }^{14}$

Finally, REIS provides information on total government transfer flows into each county. In addition to analyzing changes in total government transfers, I consider changes in their components. Total government transfers to individuals include unemployment insurance, income maintenance payments (which includes Supplemental Security Income (SSI), family assistance, and food stamps), retirement and disability insurance benefits, public medical benefits other than Medicare, Medicare, veterans' benefits, and federal education and training assistance.

To infer the causal effects of hurricanes accurately, one needs to establish a credible counterfactual. A natural starting point is to treat all unaffected counties as potential controls. In Table 3, I compare the 1969 characteristics (Panel A) and 1969-1978 trends (Panel B) of counties that do and do not experience at least one hurricane between 1979 and 2002. Columns 1 and 2 correspond to treated and all unaffected counties, respectively. Column 3 restricts the sample of unaffected counties to 21 eastern and southern states: Alabama, Connecticut, Delaware, Florida, Georgia, Louisiana, Maine, Maryland, Massachusetts, Mississippi, New Hampshire, New Jersey, New York, North Carolina, Pennsylvania, Rhode Island, South Carolina, Texas, Vermont, Virginia, and West Virginia (hereafter the "hurricane region"). Counties in these states are physically closer to the treated counties and may be more similar to them than the average county in the US.

It is immediately clear that significant differences exist between counties that do and do not experience hurricanes over this time period. Almost seventy percent of counties in the first category are coastal, compared to less than fifteen percent of those in the second category. Counties that experience hurricanes are also more populous than non-hurricane counties, have higher population densities and receive fewer per capita government transfers. Finally, the demographic composition of treated counties differs from that of the rest of the region: black residents and younger people comprise more of their populations, while people aged 65 and over comprise a smaller share. Restricting the sample of control counties to the 21 states listed above generally reduces the magnitude of these differences, but in most cases does not eliminate them.

Differences in levels are not necessarily problematic for estimation because county fixed effects can easily be included in every specification. However, differences in levels may indicate differences in trends. In Panel B, I test for differential changes in the time-varying characteristics between 1969 and 1978, before the occurrence of any hurricanes used in the estimation. Columns 1 and 2 show the total changes in affected and unaffected counties, respectively, over this time period. Here, too, significant differences exist between treated and potential control counties: hurricane counties experience greater growth in population, in the percent of residents aged 65 and over, and in transfers from the government and businesses. They exhibit a larger drop in the em-

\footnotetext{
${ }^{14}$ The current REIS data no longer include insurance payments in this transfer measure. Thus, my data on business transfers are taken from an earlier version of REIS and end in 2007.
} 
ployment rate and in the percentage of residents who are black or 20 and under. Restricting the control sample to counties in 21 hurricane states (Column 3) helps eliminate and/or reduce the magnitude of a few of these differences.

Because the unaffected counties in the 21 eastern and southern states are more similar to the treated group, I restrict my control group to unaffected counties in these states. However, as Table 3 shows, the treatment and control groups still have significant differences. A simple approach to help account for these differences is to control for them directly. Following previous studies, I do this by including year fixed effects that are allowed to vary linearly by the county's 1969 characteristics (Acemoglu, Autor, and Lyle, 2004; Hoynes and Schanzenbach, 2009). Because this does not fully eliminate trends in some cases, I also estimate a model that explicitly allows for non-parallel trends between hurricane-affected and control counties. I discuss the robustness of the results to varying the set of controls and to varying the control group in Section III.

Table 4 presents the summary statistics for the estimation sample. The average county in the sample has almost 99,000 residents; the average annual wage per job is $\$ 29,000$, while the average per capita wage is $\$ 7,300$. About $31 \%$ of the residents are 20 and under, $14 \%$ are 65 and older, and $18 \%$ are black. The average adult employment rate is only $32 \%$, reflecting the fact that County Business Patterns does not include government and some farm employment, among other categories. In rare instances, the employment rate is greater than 1, possibly due to measurement error and workers who commute from other counties. Per capita transfers from the government average $\$ 4,700$ per year, of which $\$ 1,700$ is public medical spending, \$960 is Medicare spending, \$560 is income maintenance, and $\$ 150$ is unemployment insurance. Finally, transfers from businesses average $\$ 96$ per capita per year.

\section{Empirical Strategy}

\section{A Basic Approach}

To estimate the effects of a hurricane up to ten years after its landfall, I use three complementary specifications: (1) an event study, which allows the estimated impact of a hurricane to vary flexibly over time, (2) a more efficient specification that reduces the number of post-hurricane coefficients to two and assumes that all the pre-hurricane coefficients are equal to zero, and (3) a specification that accounts for pre-trends by allowing outcomes in hurricane-affected counties to follow a different linear trend and subsequently estimates whether hurricanes cause a shift in the mean and/or a change in the trend. ${ }^{15}$ Each of the specifications has strengths and weaknesses; utilizing all three helps to identify robust results.

\footnotetext{
${ }^{15}$ I use ordinary least squares estimation throughout the paper for transparency. However, my results would be similar if I used another econometric approach such as propensity score matching/weighting or the Oaxaca-Blinder estimator (Kline, 2011; Busso, Gregory and Kline, 2013; Kline and Moretti, 2014).
} 
Throughout the analysis, the identifying assumption is that, conditional on the location and the year, the occurrence of a hurricane is uncorrelated with unobservable economic shocks. This is reasonable because even forecasting the severity of the hurricane season as a whole, much less the paths that individual hurricanes will take, is difficult. However, US counties that experience hurricanes differ systematically from counties that do not. I address this issue partly by restricting the control group to counties in 21 states that are prone to hurricanes or border on hurricane-prone states. I also allow for time trends that vary based on counties' pre-hurricane characteristics. Finally, one of the estimating equations explicitly allows for outcomes in hurricane-affected counties to be on a different linear trend.

Because unobserved heterogeneity across hurricanes is likely, I make sure to estimate every coefficient of interest using the same set of hurricanes. In practice, this means I am estimating the effects using hurricanes that made landfall between 1979 and 2002. Some of the counties in my sample experience more than one hurricane during this time period; other counties experience a hurricane in 1969-1978 or after 2002. To ensure that every coefficient of interest is estimated using the same set of hurricanes, I use only the first instance of a hurricane in any given county between 1979 and 2002 in my estimation. That is, I ignore hurricanes that occurred prior to 1979 or after 2002 as well as any hurricanes that occurred between 1979 and 2002 in a county that had already experienced a hurricane during that time period. Because hurricane hits are random, conditional on a county fixed effect, this procedure should not bias my estimates. Alternatively, I could eliminate counties that experience a hurricane prior to 1979 or after 2002 from the estimation sample altogether. However, doing so would both eliminate many counties that are good controls and significantly reduce the number of counties in the treated group. ${ }^{16}$

To maintain a consistent sample across outcome variables, I also require that all of the following key variables are not missing for a county-year observation to be included in the estimation: population, employment rate, the share of population that is $65+$ years of age, the share that is 20 years old and under, the share that is black, per capita wages, and per capita transfers from the government. ${ }^{17}$ For hurricane-affected counties, I also require that the outcome of interest not be missing in each year from ten years before to ten years after the hurricane. This ensures that the estimated effects are based on a balanced sample of hurricane-affected counties.

\section{B Econometric Specifications}

I first employ a flexible event study framework, which is useful for gauging the overall pattern of the impact of a hurricane. In addition, pre-hurricane coefficients in this specification help assess any pre-trends. To implement the event study, I regress outcomes on a set of hurricane indicators

\footnotetext{
${ }^{16}$ Restricting the set of treated counties to those that experienced only one hurricane between 1979 and 2002 does not change the results meaningfully (see Online Appendix Figure A12).

${ }^{17}$ Transfers from businesses are not included in this restriction because that data series ends in 2007.
} 
ranging from ten years before to ten years after a hurricane, controlling for county and year fixed effects and hurricane occurrence outside the time interval of interest. I also include year fixed effects that are linear in each of the following 1969 characteristics: land area; whether the county is coastal; population (in $\log$ ); the shares of the population that are black, under 20, or 65 and over; the employment rate; and per capita wages (in logs). Specifically, the estimating equation is:

$$
\begin{array}{r}
O_{c t}=\sum_{\tau=-10, \tau \neq-1}^{10} \beta_{\tau} H_{c \tau}+\alpha_{c}+\alpha_{t}+\mathbf{X}_{\mathbf{c}, \mathbf{1 9 6 9}}^{\prime} \alpha_{t} \\
+\beta_{-11} H_{c,-11}+\beta_{11} H_{c, 11}+\varepsilon_{c t}
\end{array}
$$

where $O_{c t}$ is some outcome for county $c$ in year $t$, such as the log of per capita transfers or the employment rate. The variable $H_{c \tau}$ is a hurricane indicator equal to 1 if, as of year $t$, the county experienced a hurricane $\tau$ years ago. That is, $H_{c \tau}=1$ if and only if $t-\tau_{c}^{*}=\tau$, where $\tau_{c}^{*}$ is the year a hurricane affected county $c$. I normalize the effect in the year before the hurricane ( $\tau=-1$ ) to zero. The variables $\alpha_{c}$ and $\alpha_{t}$ are county and year fixed effects. Additionally, the set of interactions $\mathbf{X}_{\mathbf{c}, \mathbf{1 9 6 9}}^{\prime} \alpha_{t}$ allows the year fixed effects to vary linearly in 1969 characteristics. Finally, $H_{c,-11}$ and $H_{c, 11}$ are indicators equal to one if a county experienced a hurricane before or after the time window of interest, respectively. Standard errors are spatially clustered following Conley (1999). I allow for spatial correlation of up to 200 kilometers around the county's centroid and for autocorrelation of order 5. My conclusions are unchanged if I cluster standard errors by county or allow for a greater degree of spatial correlation.

When estimating equation (1), I combine hurricane indicators into two-year bins to increase power. $^{18}$ The combined lags are $\tau=1$ and 2, 3 and 4, 5 and 6,7 and 8, and 9 and 10. The combined leads are the corresponding pairs of years prior to the hurricane. Year 0, which is the year that the hurricane makes landfall in a county, is not combined with any other year for symmetry and because the assumption that the effects in year 0 and any of the subsequent years are similar may not hold. In this modified specification, the average effect of combined leads 1 and 2 is assumed to be 0 , so the estimated coefficients should be interpreted as the change relative to the two years before the hurricane.

Because of its flexibility, the event study is inefficient if some coefficients are not substantially different from each other. To summarize the impact of a hurricane more concisely and further increase the power of the estimates, I use another specification that combines post-hurricane years 0-4 and 5-10 and assumes no differences between treated and control counties in the 10 years prior to the hurricane. These assumptions appear to fit the patterns observed in the data reasonably well for most outcomes. The exact specification is:

\footnotetext{
${ }^{18}$ Results using year-by-year hurricane indicators are very similar, but noisier. The full set of results is available upon request.
} 


$$
\begin{aligned}
O_{c t}= & \gamma_{1} H_{c, 0 \text { to } 4}+\gamma_{2} H_{c, 5 \text { to } 10}+\alpha_{c}+\alpha_{t}+\mathbf{X}_{\mathbf{c}, \mathbf{1 9 6 9}}^{\prime} \alpha_{t} \\
& +\beta_{-11} H_{c,-11}+\beta_{11} H_{c, 11}+\varepsilon_{c t}
\end{aligned}
$$

where $H_{c, 0 \text { to } 4}=\sum_{\tau=0}^{4} H_{c \tau}$ and $H_{c, 5 \text { to } 10}=\sum_{\tau=5}^{10} H_{c \tau}$. Because $H_{c \tau}$ can be equal to 1 at most once over any given 20-year period for a county, the only difference between equations (1) and (2) is that the latter omits hurricane indicators for the ten years before the hurricane and combines the post-hurricane indicators into two groups: years 0-4 and years 5-10. The coefficient $\gamma_{1}$ will thus reflect the mean effect on outcome $O_{c t}$ in years 0-4 after the hurricane, relative to the 10 years before, while the coefficient $\gamma_{2}$ will reflect the mean effect 5-10 years after the hurricane.

While the fixed effects and controls for characteristics eliminate many of the pre-hurricane differences between the treated and control counties, the differences persist for a few outcomes, partly because there are many outcomes of interest and a finite number of control counties. Moreover, some of the outcomes, such as population, are heavily autocorrelated, meaning that small differences between control and treated counties will grow over time. Thus, unless the control counties are identical to the treated counties in the pre-hurricane period, some differential trends are likely to arise by chance. The presence of such trends does not invalidate the idea that hurricanes are exogenous. One can still estimate a hurricane's causal effect as long as nothing is changing differentially for the treatment and control group following a hurricane that is not caused by the hurricane. In other words, one can relax the parallel trends assumption and still estimate the treatment effect. ${ }^{19}$

In order to obtain an unbiased estimate of the treatment effect when differential trends are present, one must account for them. I do this with a model that estimates (1) the mean difference in the outcome before and after a hurricane in treated counties compared with the control counties, (2) the change in the slope in the ten years after a hurricane in treated counties compared with the control counties, and (3) the difference in a linear trend between the treated and control counties in the ten years before to ten years after a hurricane. The first term is a standard difference-indifferences estimate for the mean of the outcome variable. The second term can also be interpreted as a difference-in-differences estimate, but for the slope of the outcome rather than the mean. In other words, the second term is the hurricane-driven change in the growth rate of the outcome. Finally, the third term controls for overall trend differences in some variables between treated and control counties. The specific estimating equation is as follows:

\footnotetext{
${ }^{19}$ This approach is not unprecedented in the literature. For example, models that include linear county trends also relax the parallel trends assumption, as do models that have changes in the outcome as the dependent variable. For a more detailed discussion of inference in the presence of pre-trends, see Malani and Reif (2015).
} 


$$
\begin{aligned}
O_{c t}= & \theta_{1} H_{c, 0 \text { to } 10}+\theta_{2} H_{c, 0 \text { to } 10} \times \tau+\gamma_{1} H_{c,-10 \text { to } 10} \times \tau \\
& +\alpha_{c}+\alpha_{t}+\mathbf{X}_{\mathbf{c}, \mathbf{1 9 6 9}}^{\prime} \alpha_{t}+\beta_{-11} H_{c,-11}+\beta_{11} H_{c, 11}+\varepsilon_{c t},
\end{aligned}
$$

where $H_{c, 0 \text { to } 10}=\sum_{\tau=0}^{10} H_{c \tau}, H_{c,-10 \text { to } 10}=\sum_{\tau=-10}^{10} H_{c \tau}$, and $\tau$ represents event time, as before. Thus, $\theta_{1}$ represents the average change in outcome $O_{c t}$ in the eleven years after a hurricane (the year of the hurricane and ten subsequent years) relative to the ten years before. The next term interacts $H_{c, 0 \text { to } 10}$ with the number of years since the hurricane, $\tau$. The corresponding coefficient, $\theta_{2}$, represents the hurricane-caused change in an overall linear trend. Finally, I control for the trend in the year of the hurricane, the ten years before, and the ten years after with the variable $H_{c,-10 \text { to } 10} \times \tau$, which is equal to $\tau$ if county $c$ experienced a hurricane in the ten years before or in the ten years after year $t$. The rest of the controls are as before. In order to make these estimates comparable to those in equation (2), I use equation (3) estimates to calculate the implied effects 2 and 7.5 years after a hurricane strike, which are the midpoints of the post-hurricane periods covered by $\gamma_{1}$ and $\gamma_{2}$ in equation (2). That is, I calculate $\widehat{\theta_{1}}+2 \times \widehat{\theta_{2}}$ and $\widehat{\theta_{1}}+7.5 \times \widehat{\theta_{2}}$.

I assess whether equations (2) and (3) impose too much structure on the data by testing whether their estimates are consistent with those of equation (1). For equation (2), I test the hypothesis that (a) the pre-hurricane coefficients estimated by equation (1) are jointly equal to zero and (b) the posthurricane coefficients estimated by equation (1) over the relevant time period (0-4 or 5-10 years) are equal to the respective coefficient from equation (2). For equation (3), I test the hypothesis that (a) the coefficients estimated by equation (1) follow the linear trend estimated by equation (3), on average $\left(\widehat{\gamma_{1}} \times \tau\right.$ in the pre-hurricane period and $\left(\widehat{\gamma_{1}}+\widehat{\theta}_{2}\right) \times \tau$ in the post-hurricane period) and (b) $\widehat{\beta_{0}}$, as estimated by equation (1), is equal to $1.5 \times \widehat{\gamma_{1}}+\widehat{\theta_{1}}$ (see Online Appendix for more details).

In the absence of significant pre-trends, all three models will produce similar results. When pre-trends are present, however, equations (1) and (2) will no longer give reliable estimates for the post-hurricane period. In such cases, equation (3), which allows for differential trends, will be more accurate.

Finally, to quantify the total impact of a hurricane on transfers, I use the estimates from equations (1)-(3) to compute the present value (PV) of the increase in transfers over the ten years following landfall. Specifically, I compute

$\sum_{t=0}^{10} \frac{1}{(1+r)^{t}}\left(e^{\mu+\widehat{\beta}_{t}}-e^{\mu}\right)$, where $\mu$ is the mean of a particular outcome, such as the log of total transfers per capita, in treated counties in the year before the hurricane, and $\widehat{\beta}_{t}$ is the estimated effect of a hurricane in year $t$. The estimated effects and means are exponentiated because all of the transfer measures are in logs. I set $r$ equal to 0.03 , the estimated real risk-free rate in the US around the midpoint of my sample (Siegel, 1992). Because I restrict certain coefficients to be equal to each other in my empirical approach, when I calculate the PV implied by equation (1), $\widehat{\beta}_{1}$ is set 
equal to $\widehat{\beta_{2}}, \widehat{\beta_{3}}$ is set equal to $\widehat{\beta}_{4}$, and so on. For equation (2), $\widehat{\beta}_{0}$ through $\widehat{\beta}_{4}$ are equal to each other, as are $\widehat{\beta_{5}}$ through $\widehat{\beta_{10}}$. Finally, for equation (3), each $\widehat{\beta}_{t}$ in the expression above is equal to $\widehat{\theta_{1}}+t \times \widehat{\theta_{2}}$.

\section{Results}

\section{A Changes in transfer payments following a hurricane}

Event study estimates of a hurricane's effects on per capita government transfers through general social safety net programs are shown in panel (a) of Figure $2 .{ }^{20}$ These transfers increase by $1.3 \%$ $3.9 \%$ in the ten years after the hurricane relative to a mean of about $\$ 4,700$ per capita, growing throughout the post-hurricane period. The second panel shows a hurricane's effect on per capita transfers from businesses to individuals; these spike by $8.4 \%$ in the year of a hurricane (relative to a mean of about $\$ 100$ per capita), likely reflecting private insurance payments. Unsurprisingly, the change in these transfers is not significant in any other year.

To see why transfers through the social safety net may be increasing, the next two panels consider two basic economic indicators: the average wage and the employment rate. The results show a marginally significant pre-trend in the average wage, indicating that post-hurricane estimates of equations (1) and (2) may be misleading. Following a hurricane, the wage coefficients are flat. Given the pre-trend, this could mean that wages in hurricane-affected counties are falling below their long-run trend. The employment rate is not immediately affected, but falls by a significant 0.6-0.8 percentage points 5-10 years after the hurricane.

Corresponding estimates from the more concise models, equations (2) and (3), are shown in Table 5. These confirm the results of the event study, with one exception. The estimated effect on the average wage is significantly positive in Panel A (equation (2)), which is likely due to the slight pre-trend in wages. Indeed, the trend break/mean shift estimates in Panel B (equation (3)) indicate a differential overall trend between hurricane and non-hurricane counties and show that wage growth becomes significantly more negative after a hurricane. The F-tests for these two models indicate that the constraints imposed by them are largely consistent with the data, with the exception of transfers from businesses. This is not surprising given the highly non-monotonic pattern apparent in Figure 2.

Thus, hurricanes cause non-disaster government transfers in the affected counties to increase significantly and persistently. At they same time, they also cause a decline in the employment rate and possibly a decline in the wage rate, although the latter results are not conclusive. To see if

\footnotetext{
${ }^{20}$ The point estimates and standard errors corresponding to the figures in this subsection can be found in the Online Appendix (Tables A3-A6). I also conduct tests of three null hypotheses on equation (1) estimates: (1) that the prehurricane coefficients are equal to zero, (2) that the post-hurricane coefficients are equal to zero, or (3) that the posthurricane coefficients in year 0-4 after the hurricane are equal to zero. The p-values of these three F-tests can also be found in the Appendix Tables.
} 
these results may be driven by other changes in the county, Figure 3 shows the estimated effects of a hurricane on total population and other demographics. A slight and insignificant pre-trend in population is apparent, but there is no visible change when a hurricane hits. The percentage of residents who are under 20 years of age begins growing steadily after the hurricane, while the percentage who are 65 and older falls slightly but insignificantly. The percentage of residents who are black is trending slightly downward but appears unchanged by the hurricane.

Table 6 shows corresponding estimates from equations (2) and (3). The mean shift/trend break model (equation (3)) confirms the event study: a differential population trend between the treated and control counties exists, but there is no hurricane-induced change in population. Equation (2) indicates that the fraction of the population that is 20 and under increases, while the population shares of those who are 65 and older or black falls. However, with the exception of the share of elderly, these results are not robust to the mean shift/trend break model in Panel B.

Thus, we see some evidence that the age composition of hurricane-affected counties may shift toward younger people over time, though it is far from conclusive. This result raises a concern that local government transfers may be increasing because of a change in the demographic composition rather than a hurricane's negative economic impact. While I cannot rule out this possibility definitively, suggestive evidence points against this hypothesis. Conditional on county and year fixed effects, the correlation between government transfers and the share of the population that is 65 and older is positive, while the correlation with the fraction that is 20 and younger is negative. ${ }^{21}$ Given that the share of young people increases in some specifications while that of older people drops, one would predict that government transfers would decline, not increase. Thus, it is unlikely that any demographic changes are driving the transfer changes.

To see which transfer payments are increasing, Figure 4 and Table 7 show the estimated changes in their largest components: income maintenance; public medical spending net of Medicare; disability insurance (SSDI) and Social Security; and Medicare. With few exceptions, all three models indicate that each of these major categories of government spending increases in the aftermath of a hurricane. The mean shift/trend break estimates in Panel B of Table 7 further show that the growth rates of all four categories of spending also increase, although the increase in SSDI and social security payments is only marginally significant and the implied effects 2 and 7.5 years after the hurricane are insignificant (but nearly identical in magnitude to those in Panel A). The magnitudes of the increases in these transfer components range from $1.4 \%$ to over $7 \%$, with the largest relative increases concentrated in medical and Medicare spending.

The increase in Medicare is at first puzzling in light of the apparent decline in the elderly population. However, Medicare payments also include healthcare costs of Social Security Disability

\footnotetext{
${ }^{21}$ Both correlations are highly significant. The correlation between government transfers and the fraction of the population that is black is insignificant.
} 
Insurance (SSDI) enrollees, who are automatically enrolled in Medicare after two years of disability. With any increase in SSDI enrollment following a hurricane, one would expect Medicare payments to increase as well. ${ }^{22}$ Previous studies have shown that SSDI applications are positively correlated with the unemployment rate (Autor and Duggan, 2005), and evidence suggests that higher unemployment leads to greater SSDI enrollment (Black, Daniel and Sanders, 2002; Autor and Duggan, 2003; Duggan and Imberman, 2009). ${ }^{23}$ A back-of-the-envelope calculation can help shed light on whether increased SSDI enrollment can explain the increase in Medicare payments. As Figure 4 and Table 7 show, retirement and disability payments, which include Social Security and thus SSDI, increase by at most $1.6 \%$ in the ten years after a hurricane. According to Autor and Duggan (2005), in 1985 about $10 \%$ of Social Security spending was devoted to SSDI. In turn, Social Security accounts for about $95 \%$ of all retirement and disability spending in my data. Thus, if the entire increase in retirement and disability spending is due to SSDI, this implies an upper bound of a 17\% increase in SSDI spending per capita. By contrast, between 1979 and 2002, total SSDI spending doubled from about $\$ 40$ to $\$ 80$ billion. $^{24}$

From 1974 to 2012, between $8.7 \%$ and $19.8 \%$ of Medicare spending was on the disabled under the age of 65, with the share increasing steadily over time (U.S. Department of Health and Human Services, 2013). In the mean shift/trend break estimates, annual Medicare payments per capita increase by as much as $8 \%$ relative to the year before a hurricane (corresponding estimates from equations (1) and (2) are smaller). The average Medicare payment per capita was around $\$ 875$ during my sample period. Thus, the maximum Medicare increase roughly corresponds to an additional $\$ 70$ per person per year. The average county in my sample has about 99,000 people, implying a maximum increase of $\$ 6.9$ million per affected county per year. According to the Congressional Research Service (1997), in 1995 Medicare spent about \$7,800 per non-elderly disabled beneficiary in real terms. Dividing $\$ 6.9$ million by $\$ 7,800$ suggests that an increase in the disability rolls of about 890 people per county per year (less than $1 \%$ of the average population) can account for the upper bound of the increase in Medicare spending.

The next set of results (Figure 5 and Table 8) shows the estimated increases in smaller but potentially important subcomponents of total government transfers: unemployment insurance (UI); family assistance, which includes programs like Temporary Assistance for Needy Families (TANF), its predecessor, Aid to Families with Dependent Children (AFDC), and the Earned Income Tax Credit (EITC); food stamps; and Supplemental Security Income (SSI). ${ }^{25}$ All three models show

\footnotetext{
${ }^{22}$ Other possible explanations for the increase in Medicare include long-run health effects or a reduction in private health coverage. Due to lack of data, I cannot say anything about the plausibility of these explanations.

${ }^{23}$ Unfortunately, it is not possible to obtain the number of SSDI recipients at the county level prior to 1999, and REIS does not report SSDI payments separately.

${ }^{24}$ Author's calculations using data from Social Security Administration (2015).

${ }^{25}$ Because the food stamp program was not deployed nationwide until 1975, I assume that, prior to 1975 , counties that are missing food stamp data but have non-missing total government transfers are receiving 0 food stamp transfers.
} 
significant increases in UI and family assistance but little to no change in food stamps or SSI. The increase in per capita unemployment insurance payments in the event study estimates mirrors that of the decrease in the employment rate; UI payments are $7.5 \%-12.5 \%$ higher $3-8$ years after the hurricane. They appear to be returning to pre-hurricane levels at the end of the estimation period.

In light of the increase in nearly every transfer category following a hurricane, one may have expected that both food stamps and SSI would also increase. While it is beyond the scope of this paper to further investigate the differences between these and other transfer programs, I offer a likely explanation for why SSI is unchanged. SSI is reserved for the elderly, the blind, and the disabled who have little or no income. It is in general more difficult to qualify for than SSDI. In particular, to qualify for SSI, disabled adults must have a disability that is expected to result in death, which is not a requirement of the SSDI program. Thus, if hurricanes do not increase the rate of serious disabilities, it is not surprising that increases in disability payments would operate through the SSDI program rather than the SSI program.

\section{B Heterogeneity by wind speed}

Stronger hurricanes generally cause more damage than weaker hurricanes. ${ }^{26}$ To test for heterogeneity in this dimension, I estimate how the impact of a hurricane varies by the maximum wind speed each affected county experiences. For this purpose, I replicate the trend break/mean shift specification, but split up the hurricane indicators into (a) Category 1 wind speeds (74-95 mph), (b) Category 2 wind speeds (96-110 mph), and (3) Category 3 wind speeds (111 mph and higher). ${ }^{27}$ I consider four key variables: total government transfers to individuals, total business transfers to individuals, the average wage, and the employment rate.

The results are shown in Table 9. ${ }^{28}$ As expected, the increase in government transfer payments is largest for winds of Category 3 and above. However, government transfer payments increase after even the weakest hurricanes, and I cannot statistically reject that these increases are equal to each other. The negative economic effects of stronger winds are also more severe: while there is no significant effect of Category 1 winds on the employment rate, winds that are rated Category 2 or 3 and above reduce the employment rate by about 2.4 percentage points 7.5 years after a hurricane. I can reject the null hypothesis that the employment effects of Category 1 and Category 2 winds are the same 2 years after a hurricane but not 7.5 years after. ${ }^{29}$ Finally, wages are unchanged following

I also add $\$ 1000$ prior to taking the $\log$, to avoid missing values.

${ }^{26}$ This statement holds on average but not for every storm. For example, Hurricane Sandy was only a Category 2 hurricane when it made landfall; many of the damaged areas experienced only tropical storm force winds.

${ }^{27}$ Category 4 and 5 wind speeds are not frequent enough to estimate their effects separately. Moreover, it does not appear that Category 4 and 5 winds cause more damage than Category 3 winds in my sample, at least on the county level (see the Online Appendix).

${ }^{28}$ Estimates from equations (1) and (2), which tell a similar story, can be found in the Online Appendix (Figure A1 and Table A7).

${ }^{29}$ I cannot reject equality for Category 1 and 3 winds or for Category 2 and 3 winds. 
Category 1 or 2 winds, but drop significantly after Category 3+ winds: 2 years after the hurricane, average wages are about $6 \%$ lower in counties that were affected by Category 3 winds; 7.5 years later, they are almost $13 \%$ lower. I can reject the null hypothesis that the wage effects of Category 1 and Category 3+ winds are the same. Moreover, the wage effects of Category 2 and 3+ winds are statistically different from each other 7.5 years after a hurricane.

\section{Total changes in transfers}

According to calculations in Section I.B, disaster aid given through federal disaster declarations to hurricane victims during my sample period averaged $\$ 155-\$ 160$ per capita for an average hurricane and \$400-\$425 per capita for Category 3+ wind speeds (see Table 2). In this section, I calculate the present value (PV) of wage losses and transfer payments given through various non-disaster safety nets $0-10$ years after a hurricane. The PV is calculated by $\sum_{t=0}^{10} \frac{1}{(1+r)^{t}}\left(e^{\mu+\widehat{\beta_{t}}}-e^{\mu}\right)$, where $\mu$ is the mean of a particular outcome, such as the log of per capita transfers, and $\widehat{\beta}_{t}$ is the estimated impact of a hurricane $t$ years after landfall. Columns 1-3 of Table 10 show the estimates corresponding to equations (1)-(3), respectively. The first row shows the estimated wage losses assuming a 3\% real discount rate. Here, equations (1) and (2) give unreliable estimates because of the slight pre-trend in wages; for example, equation (2) indicates wage gains following a hurricane even though it is clear from the event study that earnings do not grow after a hurricane. Equation (3) indicates an earnings loss of $\$ 850$ per capita in present value. While this number is not statistically significant, its magnitude will affect conclusions about the ability of non-disaster transfers to offset earnings losses.

The rest of the table shows estimated changes in total non-disaster transfers and their components. Here, all three equations yield similar results. The PV of all government transfers is about \$780-\$1,150 per capita, and the PV of transfers from businesses is $\$ 22-\$ 24$ per capita. Thus, posthurricane transfers from general social programs are greater than transfers from disaster-specific programs and much greater than private insurance payments. The magnitude of non-disaster transfers is very similar to (and slightly larger than) that of the earnings losses.

Recall that total hurricane-related disaster spending added up to $\$ 19$ billion between 1979 and 2002. The estimates above imply that the same hurricanes also caused an additional $\$ 44-\$ 65$ billion in social safety net transfers. ${ }^{30}$ Because the non-disaster transfers are still significantly greater 10 years after a hurricane, these estimates should be viewed as a lower bound.

Table 10 further indicates that most transfer components increase significantly following a hurricane. Specifically, public medical benefits increase by $\$ 310-\$ 600$ per capita in PV, and Medicare benefits are estimated to increase by $\$ 25-\$ 310$ per capita. Unemployment benefits increase by

\footnotetext{
${ }^{30}$ Calculated by taking the smallest and the largest estimate from Table 10 and multiplying it by the total population affected by hurricanes in my sample (56.4 million).
} 
about \$65-\$75 per capita in PV. Income maintenance increases by $\$ 120-\$ 150$ per person. Retirement and disability insurance benefits are estimated to increase by $\$ 160-\$ 190$. Per capita educational assistance is estimated to be $\$ 20-\$ 30$ smaller in the years following a hurricane. Family assistance increases by $\$ 45-\$ 55$. Finally, results for SSI benefits and food stamps are noisy. Only equation (2) estimates a significant change in SSI (a fall of about \$20). Food stamp spending is \$35 higher according to equation (1) (but only marginally significant), essentially unchanged according to equation (2), and $\$ 100$ higher according to equation (3).

Table 11 shows the PVs of earnings losses and transfers by wind speed, using estimates from equation (3). ${ }^{31}$ Losses in earnings are negative but insignificant for Category 1 and 2 wind speeds (\$490 and \$800, respectively). In counties experiencing Category 3+ wind speeds, however, earnings losses are a highly significant $\$ 4,300$. Total social safety net transfers from the government (not including disaster aid) are estimated to add up to about $\$ 1,100$ per capita for Category 1-2 winds; Category $3+$ winds result in transfers of nearly $\$ 1,700$ per capita in the ten years after the hurricane. The extent to which transfers offset earnings losses appears to be falling weakly with the strength of the hurricane: total non-disaster transfers are almost twice as large as the earnings loss for Category 1 wind speeds, slightly larger than the loss for Category 2 wind speeds, but only about forty percent of the earnings loss for Category 3 or higher wind speeds.

To put these results in context, recall that major hurricanes (Category $3+$ ) in the US during my sample period caused about $\$ 700$ per capita in direct damage, according to FEMA simulations. ${ }^{32}$ Although it is hard to precisely calculate the amount of federal disaster aid received by counties affected by these hurricanes, a reasonable estimate is $\$ 180-\$ 185$ per capita. Thus, direct disaster aid in the US offsets approximately one quarter of direct disaster damage, at least for major hurricanes. In addition, transfer payments through social safety nets appear to fully offset earnings losses except for the strongest winds. These findings are in stark contrast to Autor, Dorn and Hanson (2013), who estimate that transfers to workers hurt by trade are small relative to wage losses.

\section{Robustness of results}

Next, I discuss key robustness checks, focusing on whether the results on government transfers are sensitive to varying the controls, the control group, or the level of aggregation. The results themselves can be found in the Online Appendix or are available upon request.

Recall that the main specification includes county and year fixed effects, as well as year fixed effects interacted with 1969 county characteristics. In one robustness check, I vary the included

\footnotetext{
${ }^{31}$ Estimates using equations (1) and (2) can be found in the Online Appendix (Tables A8 and A9).

${ }^{32}$ While these estimates capture a variety of immediate damage, they do not account for the cost of temporary housing, for which disaster aid can help pay. The latter component is unlikely to be large, however, as the number of displaced households is small relative to a county's population, and the typical hurricane does not displace people for long periods of time.
} 
controls by omitting the characteristics controls (Online Appendix Figures A2-A5 and Tables A10A13), including state-specific or county-specific linear trends, and/or including state-by-year fixed effects (Figure A6, Table A14). Overall, the point estimates and significance levels are very similar across the various sets of controls, while most of the pre-trends are insignificant. ${ }^{33}$ The overall transfer estimates from the preferred specification fall between the estimates with different controls. The biggest change in estimates comes from including state-by-year fixed effects, which in general makes estimates lower in absolute value. This suggests that positive spatial spillovers might be present.

I have also probed the robustness of government transfer estimates to several variations in the control and treated groups (Figure A7 and Table A15). Specifically, I restrict the sample to (1) states that have experienced hurricanes between 1979 and 2002, (2) coastal counties, and (3) counties that experienced at least one hurricane between 1979 and 2002. I also (4) exclude the Northeastern states, (5) omit counties that fall within an MWSR but through which the center of a storm does not pass, and, finally, (6) omit unaffected neighbors of affected counties. The resulting point estimates and significance levels are very similar.

I have also varied the geographic unit of observation to test the robustness of the results to various definitions of a labor market (Figures A8 and A9). Specifically, I assume that the relevant unit of observation is either the Core Based Statistical Area or the Commuting Zone (Tolbert and Sizer, 1996) in which an affected county lies. The results do not change much. I have also varied the definitions of the employment rate and wages (Figures A10 and A11). Using the REIS definition of total employment makes the employment estimates smaller and insignificant, possibly because REIS includes government workers, whose jobs may be more secure. The earnings results are similar regardless of the definition.

A final concern is the appearance of pre-trends in a few of the outcome variables, especially population. The pre-trends likely arise because population is highly autocorrelated: with year and county fixed effects, the partial correlation between current and lagged population is 0.98 . In this case, unless the controls are a perfect match for pre-hurricane outcomes, we would expect to see a line with a non-zero slope as small differences between hurricane and non-hurricane counties grow over time. More generally, consideration of many outcomes makes it possible for some pre-trends to arise by chance. However, the transfer results are very similar whether or not they are estimated on a per-capita basis (as in the paper) or on a total basis (available upon request).

\section{Implications of the results}

I now discuss in more detail the implications of the estimates above, focusing on two key themes. First, the fiscal costs of hurricanes in the US are much higher once transfers through traditional

\footnotetext{
${ }^{33}$ These statements generally hold for other outcome variables as well.
} 
social safety nets are taken into account. Second, combined disaster and non-disaster transfers to counties affected by hurricanes offset a large share of estimated damage and wage losses, implying that victims of such disasters are better insured against them than previously thought.

Fully capturing the fiscal costs of natural disasters is important for at least three reasons. First, because of the deadweight loss of taxation, higher fiscal costs in the aftermath of a hurricane necessarily imply higher returns to ex ante mitigation expenditures. Second, knowledge of the full fiscal impacts allows a government to take appropriate steps to prepare for those impacts, for example by issuing catastrophe (CAT) bonds or setting aside funds. The fact that such costs appear to be non-trivial, at least in the US, suggests that more attention should be paid to the fiscal costs of natural disasters. Finally, according to the World Labour Report 2000, 75\% of the world's unemployed, many of them in developing countries, are not receiving any benefit payments (International Labour Office, 2000). My estimates for the US suggest that the absence of such social safety nets in developing countries may have farther-reaching implications than previously thought.

My estimates also suggest that US residents are better insured against hurricanes than presently recognized. Although how well-insured they are cannot be determined precisely without more disaggregated data, the designs of disaster and non-disaster government programs suggest that they are complementary. Disaster transfers target individuals immediately affected by the physical structural damage from a disaster, and they provide funds for restoring public infrastructure. ${ }^{34}$ Private insurance targets individuals who sustain direct disaster losses in the form of property damage. Non-disaster social insurance programs, on the other hand, are able to target individuals who are affected indirectly. For example, while the US has a disaster-related unemployment insurance program (included in the calculations of disaster-related transfers), it provides benefits only to those who can show that they lost their jobs directly as a result of the disaster. If hurricanes have lasting effects, as seems to be the case in the US, many of those affected will be unable to claim these benefits. In such cases, the presence of standard social safety net programs serves as insurance against delayed effects of natural disasters.

An important caveat is that how well-insured hurricane victims are depends not only on the comparison of average transfers to losses but also on how well the transfers target those who suffer losses. The process by which disaster aid is awarded has been shown to be affected by politics (e.g., Downton and Pielke, 2001; Garrett and Sobel, 2003). The amount of disaster aid relative to estimated damage at the hurricane level varies widely, ranging from less than 5 percent of damage to over 200 percent (see Online Appendix Table A1). Because disaster aid in the US is largely ad hoc by design, whereas other transfer programs are not, such variance is less likely to be an issue

\footnotetext{
${ }^{34}$ Disaster aid to individuals typically makes up less than half of total disaster aid; the rest is allocated to activities such as debris cleanup and restoration of public buildings and roads (FEMA, personal communication).
} 
with standing social safety nets.

Finally, whether the presence of social safety nets for those living in disaster-prone areas is welfare-improving on a national level is not straightforward to determine. On the one hand, the presence of insurance against economic losses not covered by homeowner's and flood insurance is a benefit when individuals are risk averse or credit constrained. Theoretically, such insurance may allow credit-constrained individuals to avoid moving during the recovery period and mitigate drops in wages. On the other hand, both disaster and non-disaster transfers may be creating at least two kinds of moral hazard problem. First, disaster risk is not currently accounted for in unemployment insurance premiums. This omission effectively subsidizes business activity in disaster-prone areas, which decreases social welfare. Second, insurance subsidies and free disaster aid could discourage the provision or private purchase of insurance coverage and encourage people to live in disasterprone areas. These issues make even a theoretical welfare analysis of social safety nets difficult in this context.

\section{Conclusion}

I study the fiscal impacts of hurricanes in the US by estimating how transfers through traditional social safety nets change during the ten years after a hurricane. I find that the present value of such transfers increases by $\$ 780-\$ 1,150$ per capita, mainly driven by medical spending, income maintenance, and unemployment insurance payments. The magnitude of the increase is substantially greater than disaster-related transfers, which I estimate to average $\$ 155-\$ 160$ per capita. Insurance payments increase temporarily in the year of a hurricane but add less than $\$ 25$ per capita in present value. At the same time, the employment rate declines temporarily, while the wage rate is statistically unchanged. Most transfers from traditional safety net programs occur later than government disaster transfers and insurance payments, suggesting that traditional safety net programs complement public and private disaster insurance. Comparing the magnitudes of transfer estimates to damage and wage loss estimates also suggests that a significant share of hurricane losses in the US is offset by transfers.

In contrast to my results, Autor et al. (2013) find that Trade Adjustment Assistance compensates for a trivial share of income lost due to trade. When they account for other social safety nets, over $90 \%$ of the income loss still appears uncompensated. Similarly, Deryugina and Hsiang (2014) find that the vast majority of income loss due to temperature fluctuations is not compensated for by government transfers. Thus, it appears that US residents are better insured against hurricanes than trade or weather shocks. Although determining the reason for this stark difference is beyond the scope of this paper, the difference in the response of standing social safety net payments may be due to different mechanisms by which natural disasters versus trade and weather fluctuations affect local economies. Disaster losses are also much more salient than losses due to changes in trade 
patterns over time or due to weather fluctuations, which could prompt a larger formal government response.

Government transfers may also affect the magnitude of the economic losses directly, for example by reducing the benefits to out-migration from the affected area (Notowidigdo, 2013). However, using the current research design, I cannot estimate what the effects of a US hurricane would be without social insurance programs. Given that much of the world's population is at an increasing risk of experiencing natural disasters and does not have access to social or disaster insurance (International Labour Office, 2000), the causal effect of social insurance on disaster impacts and whether it creates moral hazard are two areas that deserve further study.

My findings have three main implications for policy. First, as the fiscal costs of disasters are higher than previously thought, implementing mitigation programs is correspondingly more beneficial. Second, appropriately budgeting for disaster relief requires more funds than looking at direct disaster aid alone would suggest. Third, my findings suggest that expanding social safety nets provides benefits not only to those affected by idiosyncratic shocks and general economic downturns, but also to victims of natural disasters. 


\section{References}

Acemoglu, Daron, David Autor, and David Lyle. 2004. "Women, war, and wages: The effect of female labor supply on the wage structure at midcentury." Journal of Political Economy, 112(3): 497-551.

Autor, David, David Dorn, and Gordon Hanson. 2013. "The China Syndrome: Local Labor Market Effects of Import Competition in the United States." American Economic Review, 103(6): 2121-2168.

Autor, David H., and Mark G. Duggan. 2003. "The Rise in the Disability Rolls and the Decline in Unemployment." The Quarterly Journal of Economics, 118(1): 157-206.

Autor, David H., and Mark G. Duggan. 2005. "The growth in the Social Security Disability rolls: a fiscal crisis unfolding." The journal of economic perspectives, 20(3): 71-96.

Belasen, Ariel R., and Solomon W. Polachek. 2008. "How Hurricanes Affect Employment and Wages in Local Labor Markets." American Economic Review: Papers \& Proceedings, 98(2): 4953.

Bergeijk, Peter, and Sara Lazzaroni. 2015. "Macroeconomics of Natural Disasters: Strengths and Weaknesses of Meta-Analysis Versus Review of Literature.” Risk analysis.

Black, Dan, Kermit Daniel, and Seth Sanders. 2002. "The impact of economic conditions on participation in disability programs: Evidence from the coal boom and bust." American Economic Review, 92(1): 27-50.

Blanchard, Olivier, and Larry Katz. 1992. "Regional Evolutions." Brookings Papers on Economic Activity, 1992(1): 1-75.

Board on Natural Disasters. 1999. "Mitigation Emerges as Major Strategy for Reducing Losses Caused by Natural Disasters.” Science, 284(5422): 1943-1947.

Bouwer, Laurens M., Ryan P. Crompton, Eberhard Faust, Peter Hoppe, and Roger A. Pielke Jr. 2007. “Confronting disaster losses.” Science (Policy Forum), 318(5851): 753.

Busso, Matias, Jesse Gregory, and Patrick Kline. 2013. "Assessing the Incidence and Efficiency of a Prominent Place Based Policy." The American Economic Review, 103(2): 897-947.

Card, David. 2001. "Immigrant Inflows, Native Outflows, and the Local Labor Market Impacts of Higher Immigration.” Journal of Labor Economics, 19(1): 22-64. 
Cavallo, Eduardo, and Ilan Noy. 2010. “The Economics of Natural Disasters: A Survey.” IDB Working Paper Series No. IDB-WP-124.

Charity Nagivator. n.d.. "Charity Navigator. "Haiti Earthquake: 1 Year Later. Key Facts \& Figures."." http://www. charitynavigator.org/index. cfm?bay=content . view\&cpid=1186\#. VbojfPIHYwA, Accessed: 2015-07-30.

Congressional Research Service. 1997. "Medicare and Health Care Chartbook." United States Government Publishing Office.

Conley, Timothy G. 1999. "GMM Estimation With Cross Sectional Dependence." Journal of Econometrics, 92(1): 1-45.

Cortes, Patricia. 2008. "The Effect of Low-skilled Immigration on US Prices: Evidence from CPI Data." Journal of Political Economy, 116(3): 381-422.

Deryugina, Tatyana, and Solomon M. Hsiang. 2014. "Does The Environment Still Matter? Daily Temperature And Income In The United States.” NBER Working Paper 20750.

Downton, Mary W., and Roger A. Jr. Pielke. 2001. "Discretion Without Accountability: Politics, Flood Damage, and Climate." Natural Hazards Review, 2(4): 157-166.

Duggan, Mark, and Scott A Imberman. 2009. "Why are the disability rolls skyrocketing? The contribution of population characteristics, economic conditions, and program generosity." In Health at older ages: The causes and consequences of declining disability among the elderly. , ed. David Cutler and David Wise, 337-379. University of Chicago Press.

Freeman, Paul K., Michael Keen, and Muthukumara Mani. 2003. "Dealing with Increased Risk of Natural Disasters: Challenges and Options.” IMF Working Paper 03/197.

Garrett, Thomas A., and Russel S. Sobel. 2003. "The Political Economy of FEMA Disaster Payments." Economic Inquiry, 41(3): 496-509.

Hochrainer, Stefan. 2009. "Assessing the macroeconomic impacts of natural disasters: are there any?” World Bank Policy Research Working Paper No. 4978.

Hoynes, Hilary W, and Diane Whitmore Schanzenbach. 2009. "Consumption Responses to In-Kind Transfers: Evidence from the Introduction of the Food Stamp Program." American Economic Journal: Applied Economics, 1(4): 109-139.

Hsiang, Solomon M, and Amir S Jina. 2014. "The causal effect of environmental catastrophe on long-run economic growth: evidence from 6,700 cyclones.” NBER Working Paper No. 20352. 
International Labour Office. 2000. "World Labour Report 2000: Income Security and Social Protection in a Changing World." Geneva International Labour Office.

IPCC. 2012. "Managing the Risks of Extreme Events and Disasters to Advance Climate Change Adaptation." In A Special Report of Working Groups I and II of the Intergovernmental Panel on Climate Change. , ed. C.B. Field, V. Barros, T.F. Stocker, D. Qin, D.J. Dokken, K.L. Ebi, M.D. Mastrandrea, K.J. Mach, G.-K. Plattner, S.K. Allen, M. Tignor and P.M. Midgley. Cambridge, United Kingdom and New York, NY, USA:Cambridge University Press.

IPCC. 2013. "Summary for Policymakers." In Climate Change 2013: the Physical Science Basis. Contribution of Working Group I to the Fifth Assessment Report of the Intergovernmental Panel on Climate Change., ed. T.F. Stocker, D. Qin, G.-K. Plattner, M. Tignor, S.K. Allen, J. Boschung, A. Nauels, Y. Xia, V. Bex and P.M. Midgley. Cambridge, United Kingdom and New York, NY, USA:Cambridge University Press.

Kline, Patrick. 2011. “Oaxaca-Blinder as a reweighting estimator.” The American Economic Review: Papers and Proceedings, 101(3): 532-537.

Kline, Patrick, and Enrico Moretti. 2014. "Local Economic Development, Agglomeration Economies, and the Big Push: 100 Years of Evidence from the Tennessee Valley Authority." Quarterly Journal of Economics, 129(1): 275-331.

Kousky, Carolyn. 2012. "Informing climate adaptation: a review of the economic costs of natural disasters, their determinants, and risk reduction options." Resources for the Future Discussion Paper 12-28.

Malani, Anup, and Julian Reif. 2015. "Interpreting pre-trends as anticipation: Impact on estimated treatment effects from tort reform.” Journal of Public Economics, 124: 1-17.

Murphy, Anthony, and Eric Strobl. 2010. “The impact of hurricanes on housing prices: evidence from U.S. coastal cities.” Federal Reserve Bank of Dallas Working Paper 1009.

Notowidigdo, Matthew J. 2013. “The Incidence of Local Labor Demand Shocks.” Working Paper.

Noy, Ilan, and Aekkanush Nualsri. 2011. "Fiscal storms: public spending and revenues in the aftermath of natural disasters." Environment and Development Economics, 16(01): 113-128.

Pelham, Larissa, Edward Clay, and Tim Braunholz. 2011. "Natural disasters: what is the role for social safety nets?" SP Discussion Paper No. 1102.

Siegel, Jeremy J. 1992. "The real rate of interest from 1800-1990: A study of the US and the UK." Journal of Monetary Economics, 29(2): 227-252. 
Social Security Administration. 2015. “Annual Statistical Report on the Social Security Disability Insurance Program, 2014."

Strobl, Eric. 2011. "The Economic Growth Impact of Hurricanes: Evidence from US Coastal Counties." The Review of Economics and Statistics, 93(2): 575-589.

Sylves, R., and D. Racca. 2010. "All About Presidential Disaster Declarations.” sponsored by Public Entity Risk Institute. Newark, DE: University of Delaware, www.peripresdecusa.org (no longer available), last accessed March 2009.

Tolbert, Charles M., and Molly Sizer. 1996. "U.S. Commuting Zones and Labor Market Areas. A 1990 Update.” Economic Research Service Staff Paper No. 9614.

U.S. Department of Health and Human Services. 2013. "2013 Medicare and Medicaid Statistical Supplement." Centers for Medicare and Medicaid Services. Available at http://www.cms.gov/Research-Statistics-Data-and-Systems/ Statistics-Trends-and-Reports/MedicareMedicaidStatSupp/2013. html, Accessed July 27, 2015.

Yang, Dean. 2008. "Coping with Disaster: The Impact of Hurricanes on International Financial Flows, 1970-2002.” The B.E. Journal of Economic Analysis and Policy, 8. article 13. 


\section{Figures}

Figure 1: Spatial distribution of hurricanes, 1979-2002

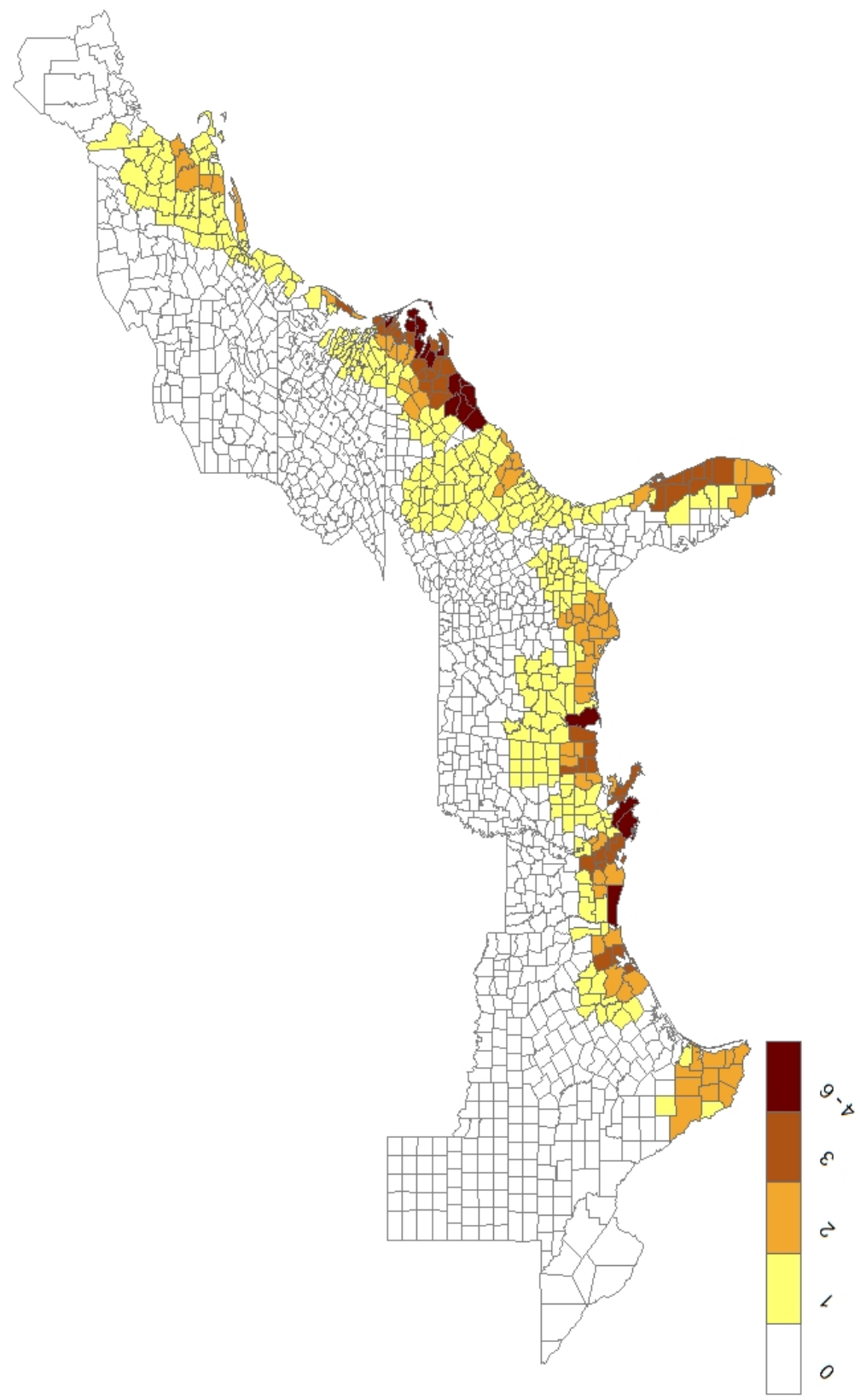

Legend shows the number of times county was affected by a hurricane between 1979 and 2002 . 
Figure 2: The effect of a hurricane on earnings and transfers

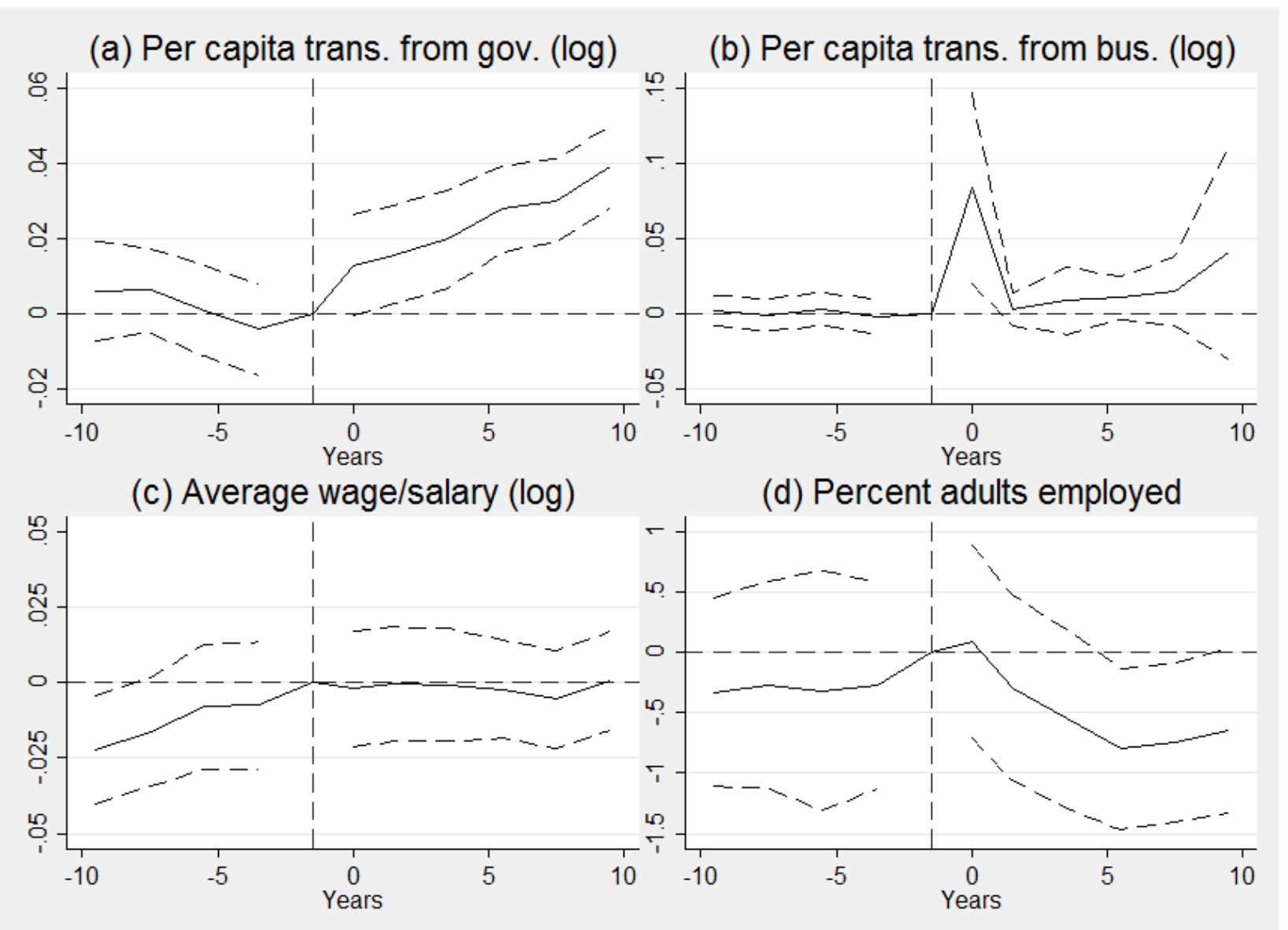

Point estimates from equation 1 and 95\% confidence intervals shown. Outcome variable displayed above corresponding plot. Standard errors allow for spatial correlation of up to 200 kilometers around the county's centroid and for autocorrelation of order 5. Controls include county fixed effects, year fixed effects, year fixed effects linear in 1969 county characteristics, and indicators for hurricane occurrence outside of the time window of interest. 
Figure 3: The effect of a hurricane on demographics

\section{(a) Population (log)}

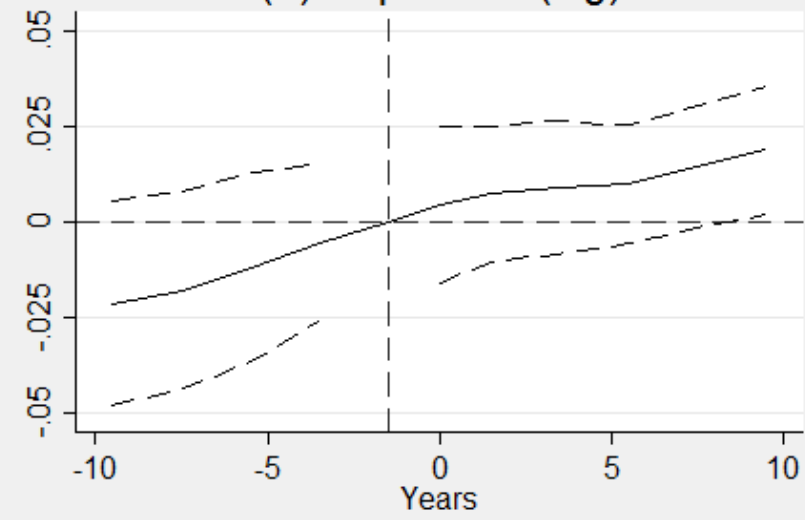

(c) Percent aged 65 and over (b) Percent aged 20 and under

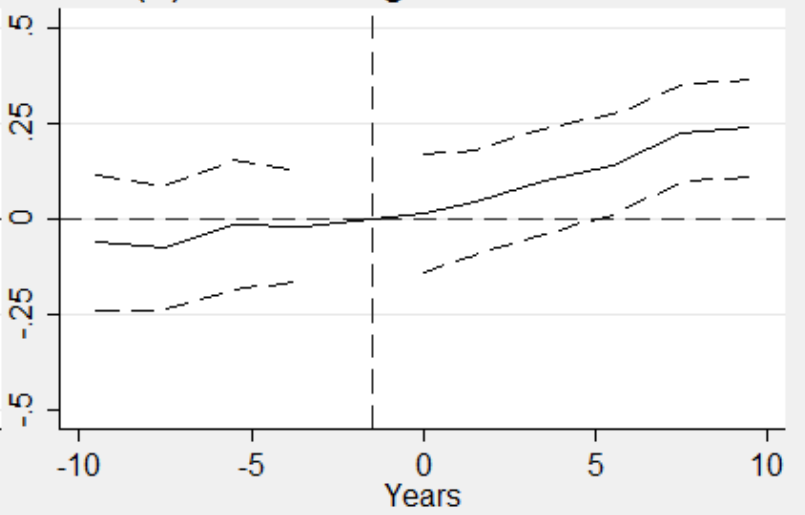

(d) Percent black

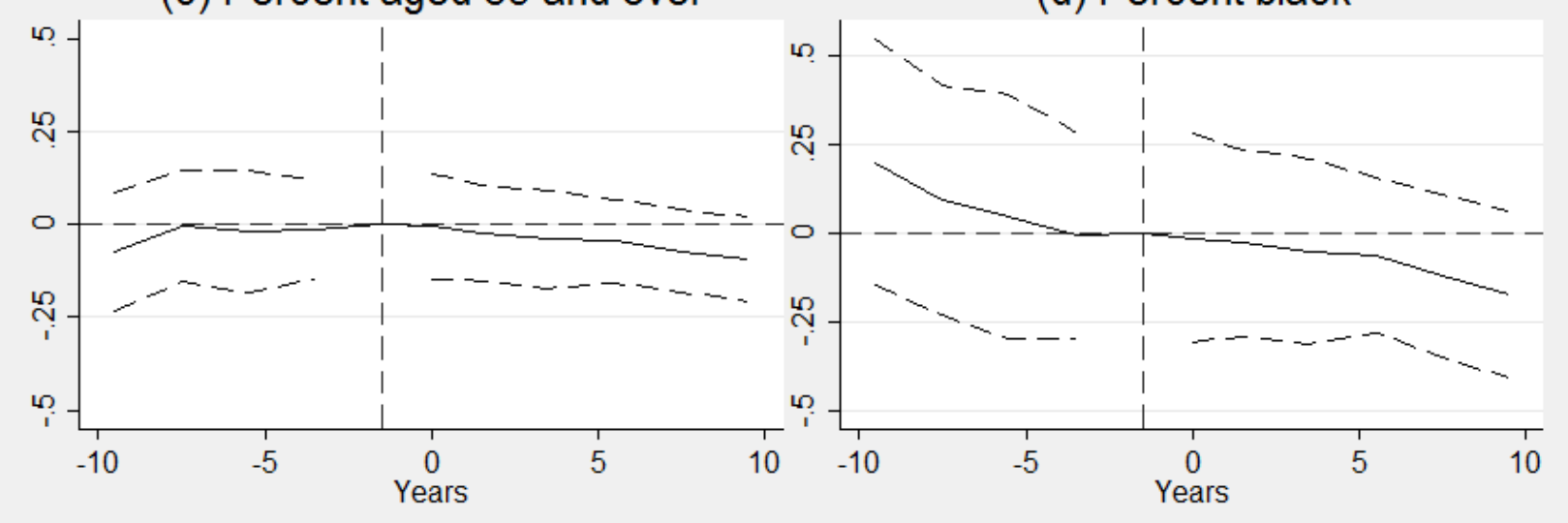

Point estimates from equation 1 and 95\% confidence intervals shown. Outcome variable displayed above corresponding plot. Standard errors allow for spatial correlation of up to 200 kilometers around the county's centroid and for autocorrelation of order 5. Controls include county fixed effects, year fixed effects, year fixed effects linear in 1969 county characteristics, and indicators for hurricane occurrence outside of the time window of interest. 
Figure 4: The effect of a hurricane on transfer components

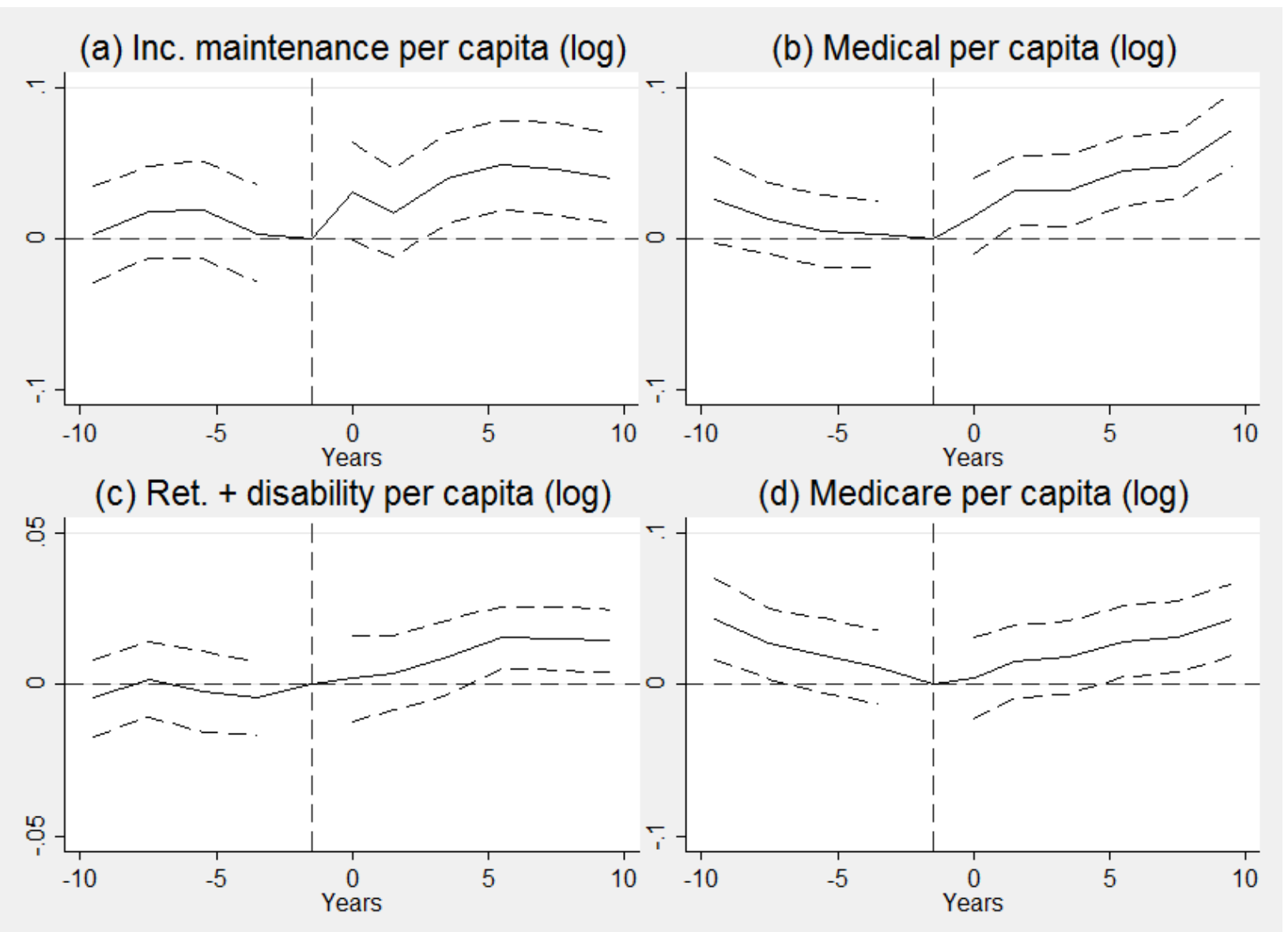

Point estimates from equation 1 and 95\% confidence intervals shown. Outcome variable displayed above corresponding plot. Standard errors allow for spatial correlation of up to 200 kilometers around the county's centroid and for autocorrelation of order 5. Controls include county fixed effects, year fixed effects, year fixed effects linear in 1969 county characteristics, and indicators for hurricane occurrence outside of the time window of interest. 
Figure 5: The effect of a hurricane on transfer components

(a) UI per capita $(\log )$

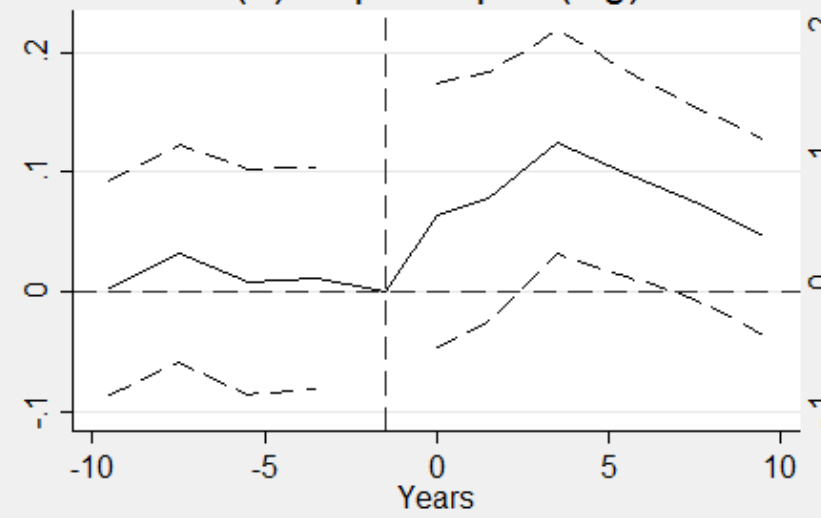

(c) Food stamps per capita (log) (b) Fam. assistance per capita (log)

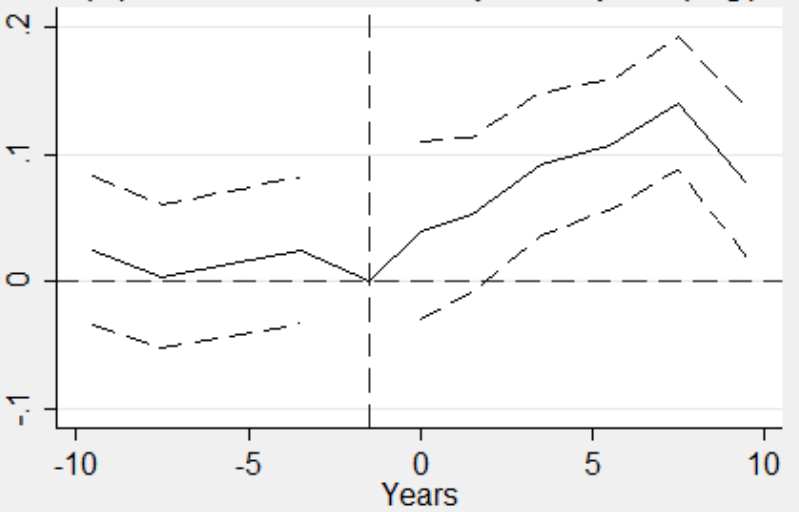

(d) SSI benefits per capita (log)
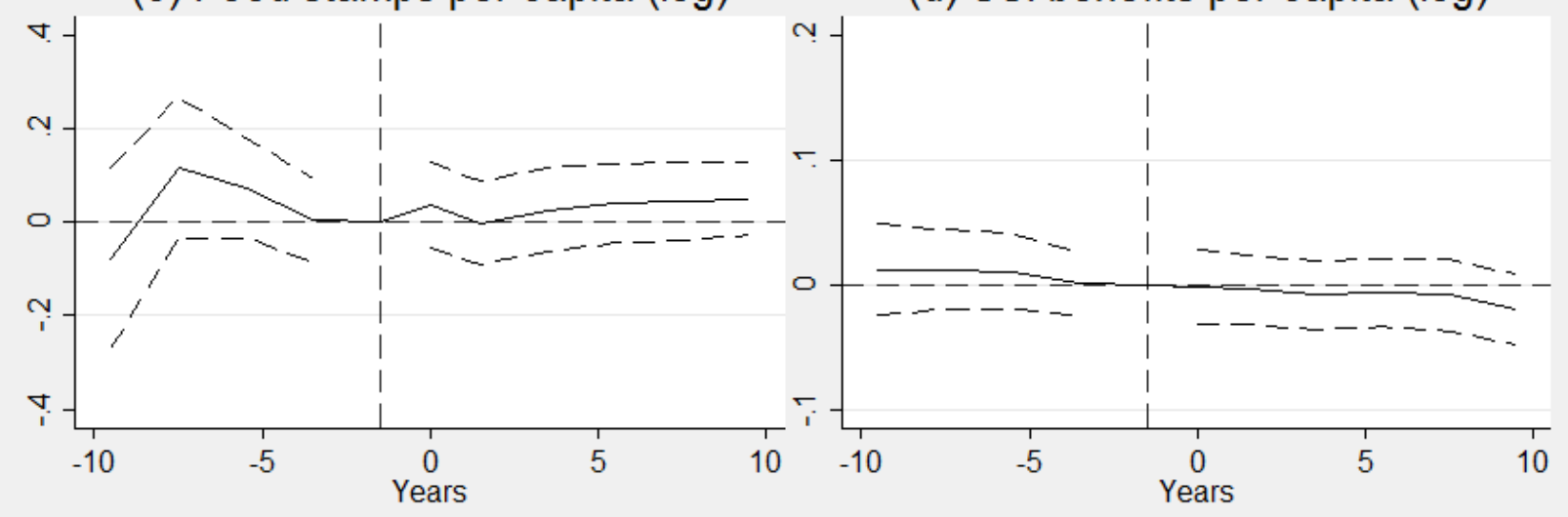

Point estimates from equation 1 and 95\% confidence intervals shown. Outcome variable displayed above corresponding plot. Standard errors allow for spatial correlation of up to 200 kilometers around the county's centroid and for autocorrelation of order 5. Controls include county fixed effects, year fixed effects, year fixed effects linear in 1969 county characteristics, and indicators for hurricane occurrence outside of the time window of interest. 


\section{Tables}

Table 1: Damages caused by major US hurricanes, 1979-2002

\begin{tabular}{|c|c|c|c|c|}
\hline & $\begin{array}{c}(1) \\
\text { Mean }\end{array}$ & $\begin{array}{c}(2) \\
\text { Standard deviation }\end{array}$ & $\begin{array}{c}(3) \\
\text { Maximum }\end{array}$ & $\begin{array}{c}\text { (4) } \\
\text { Observations }\end{array}$ \\
\hline \multicolumn{5}{|c|}{ Panel A: All counties within the MWSR } \\
\hline Total losses (1000’s) & 199,778 & $2,050,703$ & $35,426,992$ & 313 \\
\hline Total losses per capita & 698 & 2,391 & 23,298 & 313 \\
\hline Displaced households & 519 & 6,043 & 104,559 & 313 \\
\hline \multicolumn{5}{|c|}{ Panel B: Counties within the MWSR, wind speeds of 74-111 mph } \\
\hline Total losses (1000’s) & 27,622 & 198,852 & $3,173,614$ & 275 \\
\hline Total losses per capita & 235 & 642 & 6,589 & 275 \\
\hline Displaced households & 40 & 452 & 7,430 & 275 \\
\hline \multicolumn{5}{|c|}{ Panel C: Counties within the MWSR, wind speeds exceeding $111 \mathrm{mph}$} \\
\hline Total losses (1000’s) & $1,445,643$ & $5,775,323$ & $35,426,992$ & 38 \\
\hline Total losses per capita & 4,055 & 5,656 & 23,298 & 38 \\
\hline Displaced households & 3,985 & 17,098 & 104,559 & 38 \\
\hline \multicolumn{5}{|c|}{ Panel D: Neighbors of counties within the MWSR } \\
\hline Total losses (1000’s) & 1,969 & 5,800 & 62,075 & 332 \\
\hline Total losses per capita & 32 & 69 & 561 & 332 \\
\hline Displaced households & 0 & 2 & 28 & 332 \\
\hline
\end{tabular}

Source: HAZUS-MH simulation software published by FEMA. All monetary figures are in 2013 dollars. Centrally affected counties (Panel A) are those through which the storm center passes and that are classified as affected by HAZUS-MH. Panel B includes all counties that fell inside the maximum wind speed radius and are classified as affected by HAZUS-MH. Panel C shows summary statistics for counties that are directly adjacent to counties that fall within the maximum wind speed radius and are classified as affected by HAZUS-MH. 
Table 2: Descriptive statistics for hurricane aid, 1979 - 2002

\begin{tabular}{|c|c|c|c|c|c|}
\hline & (1) & (2) & (3) & (4) & $(5)$ \\
\hline & \multicolumn{3}{|c|}{ Total (millions of dollars) } & \multicolumn{2}{|c|}{ Per capita } \\
\hline & Uniform & By pop. & $\begin{array}{l}\text { By wind } \\
\text { speed }\end{array}$ & Uniform & $\begin{array}{c}\text { By wind } \\
\text { speed }\end{array}$ \\
\hline \multicolumn{6}{|c|}{ Panel A: Assuming only counties within the MWSR are given aid } \\
\hline All hurricanes in MWSR $(\mathrm{N}=612)$ & $\begin{array}{c}15 \\
(66)\end{array}$ & $\begin{array}{c}15 \\
(103)\end{array}$ & $\begin{array}{c}15 \\
(66)\end{array}$ & $\begin{array}{c}158 \\
(300)\end{array}$ & $\begin{array}{c}155 \\
(295)\end{array}$ \\
\hline HAZUS-MH hurricanes, 74+ mph $(\mathrm{N}=313)$ & $\begin{array}{c}22 \\
(90)\end{array}$ & $\begin{array}{c}22 \\
(142)\end{array}$ & $\begin{array}{c}22 \\
(91)\end{array}$ & $\begin{array}{c}186 \\
(249)\end{array}$ & $\begin{array}{c}182 \\
(239)\end{array}$ \\
\hline HAZUS-MH hurricanes, 74-111mph $(\mathrm{N}=275)$ & $\begin{array}{c}11 \\
(16)\end{array}$ & $\begin{array}{c}10 \\
(23)\end{array}$ & $\begin{array}{c}11 \\
(15)\end{array}$ & $\begin{array}{c}156 \\
(212)\end{array}$ & $\begin{array}{c}148 \\
(196)\end{array}$ \\
\hline HAZUS-MH hurricanes, $111+\mathrm{mph}(\mathrm{N}=38)$ & $\begin{array}{c}97 \\
(245)\end{array}$ & $\begin{array}{c}105 \\
(398)\end{array}$ & $\begin{array}{c}100 \\
(246)\end{array}$ & $\begin{array}{c}400 \\
(368)\end{array}$ & $\begin{array}{c}424 \\
(358)\end{array}$ \\
\hline \multicolumn{6}{|c|}{ Panel B: Assuming all counties in the declaration are given aid } \\
\hline All counties in declaration $(\mathrm{N}=1935)$ & $\begin{array}{c}6 \\
(34)\end{array}$ & $\begin{array}{c}6 \\
(52)\end{array}$ & $\begin{array}{c}9 \\
(48)\end{array}$ & $\begin{array}{c}48 \\
(101)\end{array}$ & $\begin{array}{c}71 \\
(134)\end{array}$ \\
\hline In MWSR, all hurricanes $(\mathrm{N}=612)$ & $\begin{array}{c}9 \\
(49)\end{array}$ & $\begin{array}{c}9 \\
(65)\end{array}$ & $\begin{array}{c}13 \\
(65)\end{array}$ & $\begin{array}{c}71 \\
(131)\end{array}$ & $\begin{array}{c}101 \\
(179)\end{array}$ \\
\hline In MWSR, HAZUS-MH, 74+ mph $(\mathrm{N}=313)$ & $\begin{array}{c}14 \\
(67)\end{array}$ & $\begin{array}{c}14 \\
(90)\end{array}$ & $\begin{array}{c}20 \\
(91)\end{array}$ & $\begin{array}{c}106 \\
(168)\end{array}$ & $\begin{array}{c}144 \\
(212)\end{array}$ \\
\hline In MWSR, HAZUS-MH, 74-111 mph ( $\mathrm{N}=275)$ & $\begin{array}{c}7 \\
(10)\end{array}$ & $\begin{array}{c}6 \\
(14)\end{array}$ & $\begin{array}{c}9 \\
(14)\end{array}$ & $\begin{array}{c}82 \\
(132)\end{array}$ & $\begin{array}{c}110 \\
(153)\end{array}$ \\
\hline In MWSR, HAZUS-MH, 111+ mph $(\mathrm{N}=38)$ & $\begin{array}{c}70 \\
(185)\end{array}$ & $\begin{array}{c}70 \\
(253)\end{array}$ & $\begin{array}{c}98 \\
(246)\end{array}$ & $\begin{array}{c}278 \\
(272)\end{array}$ & $\begin{array}{c}392 \\
(364)\end{array}$ \\
\hline
\end{tabular}

Source: HURDAT2, PERI disaster declarations database. Standard errors in parentheses. All amounts are in 2013 dollars. MWSR stands for 'maximum wind speed radius'. Uniform split assumes aid money is split evenly among all counties in the given sample. Proportional split by population assumes aid money is split in proportion to the population of counties in the given sample. Proportional split by wind speed assumes aid money is split in proportion to the wind speed of counties in the given sample. The per capita measures (Columns 4-5) further divide these amounts by the county's population. 
Table 3: County characteristics by 1979-2002 hurricane experience

\begin{tabular}{|c|c|c|c|}
\hline & $\begin{array}{c}\text { (1) } \\
\text { Hurricane counties }\end{array}$ & $\begin{array}{l}\text { (2) } \\
\text { Non-hurricane } \\
\text { counties }\end{array}$ & $\begin{array}{c}(3) \\
\text { Non-hurricane } \\
\text { counties in hurricane } \\
\text { states }\end{array}$ \\
\hline \multicolumn{4}{|c|}{ Panel A: 1969 county characteristics } \\
\hline Coastal indicator & 0.69 & $0.14 * * *$ & $0.18^{* * *}$ \\
\hline Land area (square miles) & 614 & $1201 * * *$ & $674 * *$ \\
\hline Population $(\log )$ & 10.57 & $9.88 * * *$ & $10.08 * * *$ \\
\hline Population density (persons/sq. mile) & 672 & $119^{* *}$ & $157 * *$ \\
\hline Employment rate (percent) & 56.81 & 57.87 & 56.37 \\
\hline Average wage $(\log )$ & 9.08 & 9.04 & 9.05 \\
\hline Per capita transfers from gov. $(\log )$ & 7.31 & $7.46^{* * * *}$ & $7.40^{* * *}$ \\
\hline Per capita transfers from bus. (log) & 4.27 & $4.28 * *$ & $4.28 * *$ \\
\hline Percent black & 26.51 & $7.14 * * *$ & $15.57 * * *$ \\
\hline Percent 65 and over & 9.60 & $12.09 * * *$ & $11.44 * * *$ \\
\hline Percent 20 and under & 40.73 & $38.41 * * *$ & $38.54 * * *$ \\
\hline \multicolumn{4}{|c|}{ Panel B: 1969-1978 changes in county characteristics } \\
\hline Chg. population (log) & 0.73 & $0.57 * * *$ & $0.62 * *$ \\
\hline Chg. pop. density & -65.39 & 28.57 & 43.08 \\
\hline Chg. employment rate & -14.65 & $-6.82 * * *$ & -12.96 \\
\hline Chg. wage (log) & 0.80 & $0.92 * *$ & 0.78 \\
\hline Chg. per capita transfers from gov. (log) & 4.15 & $3.54 * * *$ & $3.85^{* * *}$ \\
\hline Chg. per capita transfers from bus. (log) & -0.14 & $-0.16^{* *}$ & $-0.16^{*}$ \\
\hline Chg. percent black & -9.33 & $-2.69 * * *$ & $-6.76 * *$ \\
\hline Chg. percent 65 and over & 8.87 & $5.56 * * *$ & $7.26 * * *$ \\
\hline Chg. percent 20 and under & -26.57 & $-21.03 * * *$ & $-20.96 * * *$ \\
\hline Number of counties & 409 & 2904 & 899 \\
\hline
\end{tabular}

Source: 1969-1978 REIS and SEER. Monetary values are in 2013 dollars. Stars denote significant differences from hurricane counties as follows: $* 10$ percent, $* * 5$ percent, $* * * 1$ percent. Statistical tests are based on standard errors clustered by county. Number of observations varies slightly because of missing values. Hurricane states include Alabama, Connecticut, Delaware, Florida, Georgia, Louisiana, Maine, Maryland, Massachusetts, Mississippi, New Hampshire, New Jersey, New York, North Carolina, Pennsylvania, Rhode Island, South Carolina, Texas, Vermont, Virginia, and West Virginia. 
Table 4: Summary statistics

\begin{tabular}{lccccc}
\hline & $(1)$ & $(2)$ & $(3)$ & $(4)$ & $(5)$ \\
& Mean & Std. Dev. & Min & Max & Obs \\
\hline Population & 98,682 & 214,264 & 787 & $4,263,062$ & 49,245 \\
Fraction 20 and under & 0.31 & 0.05 & 0.09 & 0.51 & 49,245 \\
Fraction 65 and over & 0.14 & 0.04 & 0.01 & 0.49 & 49,245 \\
Fraction black & 0.18 & 0.18 & 0 & 0.87 & 49,245 \\
Percent adults employed & 31.94 & 14.47 & 0 & 277.16 & 49,245 \\
Average earnings per job & 28,874 & 16,048 & 3,844 & 158,846 & 49,245 \\
Average wage and salary per capita & 7,258 & 5,776 & 386 & 98,212 & 49,245 \\
Per capita transfers from gov. & 4,734 & 2,159 & 446 & 15,241 & 49,245 \\
Per capita transfers from bus. & 96 & 113 & 24 & 9,129 & 40,027 \\
Unemployment insurance per capita & 148 & 124 & 4 & 2,798 & 49,245 \\
Income maintenance per capita & 555 & 321 & 14 & 2,760 & 49,245 \\
Public medical spending per capita & 1,713 & 1,232 & 52 & 7,820 & 49,245 \\
Medicare spending per capita & 958 & 677 & 21 & 5,344 & 49,245 \\
\hline
\end{tabular}

Source: REIS and SEER. Monetary values are in 2013 dollars. Sample includes all counties in hurricane-prone states and neighboring states (total number of counties is 1166). 
Table 5: The effect of hurricanes on transfers, earnings, and the employment rate

\begin{tabular}{|c|c|c|c|c|}
\hline & $\begin{array}{c}(1) \\
\text { Per capita } \\
\text { transfers from } \\
\text { government }(\log )\end{array}$ & $\begin{array}{c}\text { (2) } \\
\text { Per capita } \\
\text { transfers from } \\
\text { business }(\log )\end{array}$ & $\begin{array}{c}(3) \\
\text { Average } \\
\text { wage/salary }(\log )\end{array}$ & $\begin{array}{l}\text { (4) } \\
\text { Percent adults } \\
\text { employed }\end{array}$ \\
\hline \multicolumn{5}{|c|}{ Panel A: concise event study (equation 2) } \\
\hline $0-4$ years after hurricane & $\begin{array}{c}0.015^{* * * *} \\
(0.003)\end{array}$ & $\begin{array}{c}0.021 * * * \\
(0.007)\end{array}$ & $\begin{array}{c}0.010 * * \\
(0.004)\end{array}$ & $\begin{array}{l}-0.001 \\
(0.001)\end{array}$ \\
\hline 5-10 years after hurricane & $\begin{array}{c}0.031 * * * \\
(0.002)\end{array}$ & $\begin{array}{l}0.022 * \\
(0.013)\end{array}$ & $\begin{array}{c}0.008 * * * \\
(0.003)\end{array}$ & $\begin{array}{c}-0.005 * * * \\
(0.001)\end{array}$ \\
\hline $\begin{array}{l}\text { p-value of model F-test } \\
\text { Observations } \\
\text { R-squared }\end{array}$ & $\begin{array}{c}0.523 \\
49,245 \\
0.961\end{array}$ & $\begin{array}{c}0.000 \\
40,027 \\
0.861\end{array}$ & $\begin{array}{c}0.567 \\
49,245 \\
0.958\end{array}$ & $\begin{array}{c}0.966 \\
49,245 \\
0.216\end{array}$ \\
\hline \multicolumn{5}{|c|}{ Panel B: implied effects of trend break model (equation 3) } \\
\hline $\begin{array}{l}\text { Implied effect after } 2 \text { years } \\
\text { Implied effect after } 7.5 \text { years }\end{array}$ & $\begin{array}{c}0.023 * * * \\
(0.006) \\
0.044 * * * \\
(0.009)\end{array}$ & $\begin{array}{c}0.026 * * * \\
(0.009) \\
0.022 \\
(0.015)\end{array}$ & $\begin{array}{l}-0.010 \\
(0.009) \\
-0.025^{*} \\
(0.013)\end{array}$ & $\begin{array}{l}-0.003 \\
(0.004) \\
-0.009 \\
(0.006)\end{array}$ \\
\hline \multicolumn{5}{|c|}{ Panel C: point estimates of trend break model (equation 3) } \\
\hline Post-hurricane indicator & $\begin{array}{c}0.016 * * * \\
(0.006)\end{array}$ & $\begin{array}{c}0.027 * * \\
(0.013)\end{array}$ & $\begin{array}{l}-0.005 \\
(0.008)\end{array}$ & $\begin{array}{l}-0.001 \\
(0.003)\end{array}$ \\
\hline Post-hurricane trend difference & $\begin{array}{c}0.004 * * * \\
(0.001)\end{array}$ & $\begin{array}{l}-0.001 \\
(0.003)\end{array}$ & $\begin{array}{c}-0.003 * * \\
(0.001)\end{array}$ & $\begin{array}{l}-0.001 * \\
(0.001)\end{array}$ \\
\hline Overall trend & $\begin{array}{l}-0.001 \\
(0.001)\end{array}$ & $\begin{array}{l}-0.000 \\
(0.001)\end{array}$ & $\begin{array}{c}0.003 * * * \\
(0.001)\end{array}$ & $\begin{array}{c}0.000 \\
(0.000)\end{array}$ \\
\hline p-value of model F-test & 0.996 & 0.001 & 1.000 & 0.959 \\
\hline Observations & 49,245 & 40,027 & 49,245 & 49,245 \\
\hline R-squared & 0.961 & 0.861 & 0.958 & 0.216 \\
\hline
\end{tabular}

Estimated using equations 2 and 3. Significance levels: * 10 percent, ** 5 percent, *** 1 percent. Standard errors (in parentheses) clustered spatially, allowing for spatial correlation of up to 200 kilometers around the county's centroid and for autocorrelation of order 5. Controls include year fixed effects, county fixed effects, trends linear in 1969 county characteristics, and dummies for hurricane occurrence outside of the time window of interest. 
Table 6: The effect of hurricanes on demographics

\begin{tabular}{|c|c|c|c|c|}
\hline & $\begin{array}{c}\text { (1) } \\
\text { Population (log) }\end{array}$ & $\begin{array}{l}\text { (2) } \\
\text { Percent } 20 \text { and } \\
\text { under }\end{array}$ & $\begin{array}{l}\text { (3) } \\
\text { Percent } 65 \text { and } \\
\text { older }\end{array}$ & $\begin{array}{c}\text { (4) } \\
\text { Percent black }\end{array}$ \\
\hline \multicolumn{5}{|c|}{ Panel A: concise event study (equation 2) } \\
\hline $0-4$ years after hurricane & $\begin{array}{c}0.018 * * * \\
(0.004)\end{array}$ & $\begin{array}{c}0.091 * * * \\
(0.034)\end{array}$ & $\begin{array}{l}-0.004 \\
(0.027)\end{array}$ & $\begin{array}{c}-0.096^{*} \\
(0.059)\end{array}$ \\
\hline $5-10$ years after hurricane & $\begin{array}{c}0.025^{* * * *} \\
(0.003)\end{array}$ & $\begin{array}{c}0.233 * * * \\
(0.024)\end{array}$ & $\begin{array}{c}-0.048^{* * * *} \\
(0.009)\end{array}$ & $\begin{array}{c}-0.180 * * * \\
(0.018)\end{array}$ \\
\hline p-value of model F-test & 0.840 & 0.915 & 0.995 & 0.982 \\
\hline Observations & 49,245 & 49,245 & 49,245 & 49,245 \\
\hline R-squared & 0.402 & 0.929 & 0.600 & 0.197 \\
\hline \multicolumn{5}{|c|}{ Panel B: implied effects of trend break model (equation 3) } \\
\hline Implied effect after 2 years & $\begin{array}{l}-0.002 \\
(0.012)\end{array}$ & $\begin{array}{c}0.029 \\
(0.078)\end{array}$ & $\begin{array}{l}-0.052 \\
(0.074)\end{array}$ & $\begin{array}{c}0.090 \\
(0.157)\end{array}$ \\
\hline Implied effect after 7.5 years & $\begin{array}{l}-0.010 \\
(0.019)\end{array}$ & $\begin{array}{c}0.121 \\
(0.123)\end{array}$ & $\begin{array}{l}-0.137 \\
(0.111)\end{array}$ & $\begin{array}{c}0.133 \\
(0.244)\end{array}$ \\
\hline \multicolumn{5}{|c|}{ Panel C: point estimates of trend break model (equation 3) } \\
\hline Post-hurricane indicator & $\begin{array}{c}0.000 \\
(0.010)\end{array}$ & $\begin{array}{l}-0.005 \\
(0.067)\end{array}$ & $\begin{array}{l}-0.021 \\
(0.064)\end{array}$ & $\begin{array}{c}0.075 \\
(0.134)\end{array}$ \\
\hline Post-hurricane trend difference & $\begin{array}{l}-0.001 \\
(0.002)\end{array}$ & $\begin{array}{c}0.017 \\
(0.011)\end{array}$ & $\begin{array}{l}-0.015^{*} \\
(0.009)\end{array}$ & $\begin{array}{c}0.008 \\
(0.020)\end{array}$ \\
\hline Overall trend & $\begin{array}{l}0.003 * \\
(0.002)\end{array}$ & $\begin{array}{c}0.009 \\
(0.010) \\
\end{array}$ & $\begin{array}{c}0.007 \\
(0.009)\end{array}$ & $\begin{array}{l}-0.025 \\
(0.019)\end{array}$ \\
\hline p-value of model F-test & 1.000 & 1.000 & 1.000 & 1.000 \\
\hline Observations & 49,245 & 49,245 & 49,245 & 49,245 \\
\hline R-squared & 0.402 & 0.929 & 0.600 & 0.197 \\
\hline
\end{tabular}

Estimated using equations 2 and 3. Significance levels: $* 10$ percent, $* * 5$ percent, $* * * 1$ percent. Standard errors (in parentheses) clustered spatially, allowing for spatial correlation of up to 200 kilometers around the county's centroid and for autocorrelation of order 5. Controls include year fixed effects, county fixed effects, trends linear in 1969 county characteristics, and dummies for hurricane occurrence outside of the time window of interest. 
Table 7: The effect of hurricanes on transfer components

\begin{tabular}{|c|c|c|c|c|}
\hline & $\begin{array}{l}(1) \\
\text { Per capita income } \\
\text { maintenance } \\
(\log )\end{array}$ & $\begin{array}{c}\text { (2) } \\
\text { Per capita } \\
\text { medical (log) }\end{array}$ & $\begin{array}{c}\text { (3) } \\
\text { Per capita } \\
\text { disability/soc. } \\
\text { sec. }(\log )\end{array}$ & $\begin{array}{c}(4) \\
\text { Per capita } \\
\text { Medicare }(\log )\end{array}$ \\
\hline \multicolumn{5}{|c|}{ Panel A: concise event study (equation 2) } \\
\hline $0-4$ years after hurricane & $\begin{array}{c}0.021 * * * \\
(0.008)\end{array}$ & $\begin{array}{c}0.019 * * * \\
(0.006)\end{array}$ & $\begin{array}{c}0.007 * * * \\
(0.003)\end{array}$ & $\begin{array}{c}-0.006 \\
(0.006)\end{array}$ \\
\hline $5-10$ years after hurricane & $\begin{array}{c}0.037 * * * \\
(0.007)\end{array}$ & $\begin{array}{c}0.046^{* * * *} \\
(0.006)\end{array}$ & $\begin{array}{c}0.017 * * * \\
(0.001)\end{array}$ & $\begin{array}{c}0.015^{* * *} \\
(0.005)\end{array}$ \\
\hline $\begin{array}{l}\text { p-value of model F-test } \\
\text { Observations } \\
\text { R-squared }\end{array}$ & $\begin{array}{c}0.864 \\
49,245 \\
0.791\end{array}$ & $\begin{array}{c}0.462 \\
49,245 \\
0.962\end{array}$ & $\begin{array}{c}0.981 \\
49,245 \\
0.917\end{array}$ & $\begin{array}{c}0.120 \\
49,245 \\
0.964\end{array}$ \\
\hline \multicolumn{5}{|c|}{ Panel B: implied effects of trend break model (equation 3) } \\
\hline $\begin{array}{l}\text { Implied effect after } 2 \text { years } \\
\text { Implied effect after } 7.5 \text { years }\end{array}$ & $\begin{array}{l}0.029 * \\
(0.015) \\
0.047 * * \\
(0.023)\end{array}$ & $\begin{array}{c}0.041 * * * \\
(0.012) \\
0.085 * * * \\
(0.019)\end{array}$ & $\begin{array}{c}0.007 \\
(0.006) \\
0.015 \\
(0.009)\end{array}$ & $\begin{array}{c}0.033 * * * \\
(0.012) \\
0.081 * * * \\
(0.019)\end{array}$ \\
\hline \multicolumn{5}{|c|}{ Panel C: point estimates of trend break model (equation 3) } \\
\hline Post-hurricane indicator & $\begin{array}{l}0.023 * \\
(0.014)\end{array}$ & $\begin{array}{c}0.025^{* *} \\
(0.011)\end{array}$ & $\begin{array}{c}0.005 \\
(0.006)\end{array}$ & $\begin{array}{c}0.015 \\
(0.011)\end{array}$ \\
\hline Post-hurricane trend difference & $\begin{array}{c}0.003 \\
(0.002)\end{array}$ & $\begin{array}{c}0.008 * * * \\
(0.002)\end{array}$ & $\begin{array}{l}0.001 * \\
(0.001)\end{array}$ & $\begin{array}{c}0.009 * * * \\
(0.002)\end{array}$ \\
\hline Overall trend & $\begin{array}{l}-0.001 \\
(0.002)\end{array}$ & $\begin{array}{c}-0.003 * * \\
(0.002)\end{array}$ & $\begin{array}{c}0.000 \\
(0.001)\end{array}$ & $\begin{array}{c}-0.005 * * * \\
(0.001)\end{array}$ \\
\hline p-value of model F-test & 0.826 & 0.984 & 0.973 & 1.000 \\
\hline Observations & 49,245 & 49,245 & 49,245 & 49,245 \\
\hline R-squared & 0.791 & 0.962 & 0.917 & 0.964 \\
\hline
\end{tabular}

Estimated using equations 2 and 3. Significance levels: $* 10$ percent, $* * 5$ percent, $* * * 1$ percent. Standard errors (in parentheses) clustered spatially, allowing for spatial correlation of up to 200 kilometers around the county's centroid and for autocorrelation of order 5. Controls include year fixed effects, county fixed effects, trends linear in 1969 county characteristics, and dummies for hurricane occurrence outside of the time window of interest. 
Table 8: The effect of hurricanes on transfer components

\begin{tabular}{|c|c|c|c|c|}
\hline & $\begin{array}{l}(1) \\
\text { Per capita UI } \\
(\log )\end{array}$ & $\begin{array}{l}\text { (2) } \\
\text { Per capita family } \\
\text { assistance (log) }\end{array}$ & $\begin{array}{c}\text { (3) } \\
\text { Per capita food } \\
\text { stamps }(\log )\end{array}$ & $\begin{array}{l}(4) \\
\text { Per capita SSI } \\
\quad(\log )\end{array}$ \\
\hline \multicolumn{5}{|c|}{ Panel A: concise event study (equation 2) } \\
\hline $0-4$ years after hurricane & $\begin{array}{c}0.084 * * * \\
(0.023)\end{array}$ & $\begin{array}{c}0.052 * * * \\
(0.016)\end{array}$ & $\begin{array}{l}-0.005 \\
(0.032)\end{array}$ & $\begin{array}{c}-0.012 \\
(0.008)\end{array}$ \\
\hline $5-10$ years after hurricane & $\begin{array}{c}0.062 * * * \\
(0.017)\end{array}$ & $\begin{array}{c}0.095 * * * \\
(0.013)\end{array}$ & $\begin{array}{c}0.021 \\
(0.031)\end{array}$ & $\begin{array}{c}-0.019 * * \\
(0.008)\end{array}$ \\
\hline p-value of model F-test & 0.888 & 0.509 & 0.790 & 0.995 \\
\hline Observations & 49,245 & 46,376 & 49,098 & 49,157 \\
\hline R-squared & 0.626 & 0.541 & 0.565 & 0.513 \\
\hline \multicolumn{5}{|c|}{ Panel B: implied effects of trend break model (equation 3) } \\
\hline Implied effect after 2 years & $\begin{array}{c}0.090 * * \\
(0.045)\end{array}$ & $\begin{array}{c}0.066^{* * *} \\
(0.029)\end{array}$ & $\begin{array}{l}-0.024 \\
(0.062)\end{array}$ & $\begin{array}{c}0.003 \\
(0.015)\end{array}$ \\
\hline Implied effect after 7.5 years & $\begin{array}{c}0.076 \\
(0.065)\end{array}$ & $\begin{array}{c}0.107 * * \\
(0.043)\end{array}$ & $\begin{array}{l}-0.016 \\
(0.109)\end{array}$ & $\begin{array}{c}0.004 \\
(0.024)\end{array}$ \\
\hline \multicolumn{5}{|c|}{ Panel C: point estimates of trend break model (equation 3) } \\
\hline Post-hurricane indicator & $\begin{array}{c}0.095 * * \\
(0.041)\end{array}$ & $\begin{array}{l}0.052 * \\
(0.027)\end{array}$ & $\begin{array}{l}-0.027 \\
(0.049)\end{array}$ & $\begin{array}{c}0.002 \\
(0.013)\end{array}$ \\
\hline Post-hurricane trend difference & $\begin{array}{l}-0.003 \\
(0.006)\end{array}$ & $\begin{array}{l}0.007 * \\
(0.004)\end{array}$ & $\begin{array}{c}0.001 \\
(0.010)\end{array}$ & $\begin{array}{c}0.000 \\
(0.002)\end{array}$ \\
\hline Overall trend & $\begin{array}{l}-0.001 \\
(0.005)\end{array}$ & $\begin{array}{l}-0.001 \\
(0.003)\end{array}$ & $\begin{array}{c}0.003 \\
(0.010)\end{array}$ & $\begin{array}{l}-0.002 \\
(0.002)\end{array}$ \\
\hline p-value of model F-test & 0.866 & 0.395 & 0.638 & 1.000 \\
\hline Observations & 49,245 & 46,376 & 49,098 & 49,157 \\
\hline R-squared & 0.626 & 0.541 & 0.565 & 0.513 \\
\hline
\end{tabular}

Estimated using equations 2 and 3. Significance levels: $* 10$ percent, $* * 5$ percent, $* * * 1$ percent. Standard errors (in parentheses) clustered spatially, allowing for spatial correlation of up to 200 kilometers around the county's centroid and for autocorrelation of order 5. Controls include year fixed effects, county fixed effects, trends linear in 1969 county characteristics, and dummies for hurricane occurrence outside of the time window of interest. 
Table 9: The effect of hurricanes by wind speed, mean shift/trend break (model 3)

\begin{tabular}{|c|c|c|c|c|}
\hline & $\begin{array}{c}(1) \\
\text { Per capita } \\
\text { transfers from } \\
\text { government } \\
(\log )\end{array}$ & $\begin{array}{c}(2) \\
\text { Per capita } \\
\text { transfers from } \\
\text { business (log) }\end{array}$ & $\begin{array}{c}(3) \\
\text { Average } \\
\text { wage/salary } \\
(\log )\end{array}$ & $\begin{array}{l}\text { (4) } \\
\text { Percent adults } \\
\text { employed }\end{array}$ \\
\hline \multicolumn{5}{|c|}{ Panel A: implied effects of trend break model (equation 3) } \\
\hline Implied effect after 2 years, category 1 & $\begin{array}{c}0.022 * * * \\
(0.007)\end{array}$ & $\begin{array}{c}0.014 * * \\
(0.007)\end{array}$ & $\begin{array}{l}-0.005 \\
(0.010)\end{array}$ & $\begin{array}{c}0.001 \\
(0.004)\end{array}$ \\
\hline Implied effect after 7.5 years, category 1 & $\begin{array}{c}0.043 * * * \\
(0.010)\end{array}$ & $\begin{array}{c}0.020 \\
(0.014)\end{array}$ & $\begin{array}{l}-0.015 \\
(0.015)\end{array}$ & $\begin{array}{l}-0.003 \\
(0.006)\end{array}$ \\
\hline Implied effect after 2 years, category 2 & $\begin{array}{l}0.023^{*} \\
(0.012)\end{array}$ & $\begin{array}{c}0.027 \\
(0.017)\end{array}$ & $\begin{array}{l}-0.011 \\
(0.018)\end{array}$ & $\begin{array}{c}-0.016^{* * *} \\
(0.005)\end{array}$ \\
\hline Implied effect after 7.5 years, category 2 & $\begin{array}{c}0.042 * * \\
(0.018)\end{array}$ & $\begin{array}{c}0.011 \\
(0.018)\end{array}$ & $\begin{array}{l}-0.022 \\
(0.025)\end{array}$ & $\begin{array}{c}-0.024^{*} \\
(0.014)\end{array}$ \\
\hline Implied effect after 2 years, category 3 & $\begin{array}{c}0.038 * * \\
(0.017)\end{array}$ & $\begin{array}{c}0.110^{* *} \\
(0.056)\end{array}$ & $\begin{array}{c}-0.059 * * \\
(0.027)\end{array}$ & $\begin{array}{l}-0.012 \\
(0.009)\end{array}$ \\
\hline Implied effect after 7.5 years, category 3 & $\begin{array}{c}0.062 * * \\
(0.024)\end{array}$ & $\begin{array}{c}0.052 \\
(0.060)\end{array}$ & $\begin{array}{c}-0.127 * * * \\
(0.039)\end{array}$ & $\begin{array}{l}-0.024^{*} \\
(0.014)\end{array}$ \\
\hline \multicolumn{5}{|c|}{ Panel B: point estimates of trend break model (equation 3) } \\
\hline Post-hurricane indicator, category 1 & $\begin{array}{c}0.014 * * \\
(0.006)\end{array}$ & $\begin{array}{c}0.012 \\
(0.010)\end{array}$ & $\begin{array}{l}-0.002 \\
(0.009)\end{array}$ & $\begin{array}{c}0.003 \\
(0.004)\end{array}$ \\
\hline Post-hurricane trend difference, category 1 & $\begin{array}{c}0.004 * * * \\
(0.001)\end{array}$ & $\begin{array}{c}0.001 \\
(0.002)\end{array}$ & $\begin{array}{c}-0.002 \\
(0.001)\end{array}$ & $\begin{array}{l}-0.001 \\
(0.001)\end{array}$ \\
\hline Post-hurricane indicator, category 2 & $\begin{array}{c}0.016 \\
(0.011)\end{array}$ & $\begin{array}{c}0.033 \\
(0.024)\end{array}$ & $\begin{array}{l}-0.007 \\
(0.017)\end{array}$ & $\begin{array}{l}-0.014 \\
(0.009)\end{array}$ \\
\hline Post-hurricane trend difference, category 2 & $\begin{array}{c}0.003 * * \\
(0.002)\end{array}$ & $\begin{array}{l}-0.003 \\
(0.004)\end{array}$ & $\begin{array}{l}-0.002 \\
(0.002)\end{array}$ & $\begin{array}{l}-0.001 \\
(0.001)\end{array}$ \\
\hline Post-hurricane indicator, category 3 & $\begin{array}{l}0.029^{*} \\
(0.015)\end{array}$ & $\begin{array}{c}0.131 \\
(0.081)\end{array}$ & $\begin{array}{l}-0.034 \\
(0.024)\end{array}$ & $\begin{array}{l}-0.008 \\
(0.008)\end{array}$ \\
\hline Post-hurricane trend difference, category 3 & $\begin{array}{c}0.004 * * \\
(0.002)\end{array}$ & $\begin{array}{l}-0.011 \\
(0.015)\end{array}$ & $\begin{array}{c}-0.012 * * * \\
(0.003)\end{array}$ & $\begin{array}{l}-0.002 * \\
(0.001)\end{array}$ \\
\hline Mean of dep. var. & 8.354 & 4.450 & 1.698 & 0.319 \\
\hline Observations & 49,245 & 40,027 & 49,245 & 49,245 \\
\hline R-squared & 0.961 & 0.861 & 0.958 & 0.216 \\
\hline
\end{tabular}

Significance levels: * 10 percent, $* * 5$ percent, $* * * 1$ percent. Standard errors (in parentheses) clustered spatially, allowing for spatial correlation of up to 200 kilometers around the county's centroid and for autocorrelation of order 5. All regressions include year and county fixed effects and indicators for hurricane occurrence outside of the time window of interest. Overall trend estimates by category not shown. 
Table 10: Total change in various transfers (present discounted value)

\begin{tabular}{|c|c|c|c|}
\hline & $\begin{array}{c}\text { (1) } \\
\text { Event study (Eq. } \\
1)\end{array}$ & $\begin{array}{c}(2) \\
\text { Combined (Eq. 2) }\end{array}$ & $\begin{array}{c}\text { (3) } \\
\text { Trend break (Eq. } \\
\text { 3) }\end{array}$ \\
\hline Average wage/salary & -79 & $441 * * *$ & -850 \\
\hline Transfers from businesses (private insurance) & $23 * * *$ & $22 * * *$ & $24 * * *$ \\
\hline All non-disaster transfers from government $=$ & $831 * * *$ & $778 * * *$ & $1150 * * *$ \\
\hline Unemployment payments + & $74 * *$ & $64 * * *$ & 73 \\
\hline Public medical benefits + & $394 * * *$ & $310 * * *$ & $601 * * *$ \\
\hline Medicare benefits + & $132 * * *$ & 26 & $313 * * *$ \\
\hline Retirement and disability insurance benefits + & $162 * *$ & $192 * * *$ & 173 \\
\hline Federal educational assistance + & $-20 * *$ & $-21 * * *$ & $-32 * *$ \\
\hline Income maintenance $=$ & $152 * * *$ & $117 * * *$ & $154 * *$ \\
\hline Family assistance + & $55 * * *$ & $46 * * *$ & $54 * *$ \\
\hline SSI benefits + & -10 & $-19 * *$ & 4 \\
\hline Food stamps & $36^{*}$ & -14 & $100 * *$ \\
\hline
\end{tabular}

Significance levels: $* 10$ percent, $* * 5$ percent, $* * * 1$ percent. Table shows present discounted value of additional inflows of various transfers $0-10$ years after the hurricane. Assumed interest rate is 3 percent. Estimated with a nonlinear combination of coefficients from Equations 1, 2, and 3.

Table 11: Total change in transfer components by hurricane category (present discounted value)

\begin{tabular}{|c|c|c|c|}
\hline & $\begin{array}{c}\text { (1) } \\
\text { Category } 1\end{array}$ & $\begin{array}{c}(2) \\
\text { Category } 2\end{array}$ & $\begin{array}{c}(3) \\
\text { Category 3+ }\end{array}$ \\
\hline Average wage/salary & -492 & -800 & $-4333 * * *$ \\
\hline Transfers from businesses (private insurance) & $17 * *$ & 20 & $86^{* *}$ \\
\hline All non-disaster transfers from government $=$ & $1107 * * *$ & $1100 * *$ & $1698 * *$ \\
\hline Unemployment payments + & 46 & 66 & $421 * * *$ \\
\hline Public medical benefits + & $633 * * *$ & $583 * *$ & 361 \\
\hline Medicare benefits + & $353 * * *$ & 211 & 140 \\
\hline Retirement and disability insurance benefits + & 164 & 119 & 402 \\
\hline Federal educational assistance + & $-33 * *$ & -28 & -45 \\
\hline Income maintenance $=$ & $188 * *$ & -84 & $515 * *$ \\
\hline SSI benefits + & -23 & 66 & $128 *$ \\
\hline Food stamps + & $94 * *$ & 38 & $383 * *$ \\
\hline Family assistance & 38 & $95 * *$ & $138^{*}$ \\
\hline
\end{tabular}

Significance levels: $* 10$ percent, $* * 5$ percent, $* * * 1$ percent. Table shows present discounted value of additional inflows of various transfers 0-10 years after the hurricane by hurricane category. Assumed interest rate is 3 percent. Estimated with a nonlinear combination of coefficients from Equation 3. 